Boston University School of Law

Scholarly Commons at Boston University School of Law

Faculty Scholarship

1975

Medical Malpractice Litigation under National Health Insurance:

Essential or Expendable

George J. Annas

Follow this and additional works at: https://scholarship.law.bu.edu/faculty_scholarship

Part of the Health Law and Policy Commons, and the Insurance Law Commons 


\title{
MEDICAL MALPRACTICE LITIGATION UNDER NATIONAL HEALTH INSURANCE: ESSENTIAL OR EXPENDABLE? $\dagger$
}

\author{
George J. AnNas, * Barbara F. Katz, ** \\ ROBERT G. TRAKIMAS**:*
}

"Medical malpractice" denotes the basis for a civil action brought by a patient against a physician for injuries resulting from neghigence. The current inethod for compensating victims of these occurrences is primarily a fault-and-liability insurance system. ${ }^{1}$ The first principle of tort liability is that the party at fault pays for the dannage inflicted upon an innocent victim. Whether a doctor is at fault is determined in an adversary proceeding, witl both the doctor and the patient represented by counsel. The triers of fact have the task of ascertaining whether

† Copyright (C) 1976 by George J. Annas.

* B.A. 1967, Harvard College; J.D. 1970, Harvard Law School; M.P.H. 1972, Harvard School of Public Health. Director, Center for Law and Health Sciences, Boston University; Assistant Professor, Boston University School of Medicine.

** B.A. 1972, Boston University; J.D. 1974, Boston University School of Law. Staff Attorney, Center for Law and Health Sciences, Boston University.

*** A.B. 1972, University of Michigan; J.D. 1976, Boston University School of Law.

THE FOLLOWING CITATION WILL BE USED IN THIS ARTICLE:

U.S. Dep't of Health, Education and Welfare, Report of the Secretary's Commission on Medical Malpractice (1973) [hereinafter cited as Medical Malpractice REPORT].

1. See generally Keeton, Compensation for Medical Accidents, 121 U. PA. L. Rev. 590 (1973). This system has been severely criticized by advocates of the "no-fault" insurance concept. See J. O'CONNELI, ENDING INsult To INJURY (1975); Dornette, Medical Injury Insurance-A Possible Remedy for the Malpractice Problem, 78 CASB \& Comment 25 (Sept.-Oct. 1973); Dornette, Medical Injury Insurance-Proposed Model Legislation, J. LEGAL MED. 24 (Mar. 1975); Havighurst \& Tancredi, "Medical Adversity Insurance"-A No-Fault Approach to Medical Malpractice and Quality Assurance, 613 INs. L.J. 69 (1974); O'Connell, Elective No-Fault Liability Insurance for All Kinds of Accidents: A Proposal, 608 INs. L.J. 495 (1973); O'Connell, The Best Way to Adapt No Fault Insurance to Malpractice, MED. EcoN., June 23, 1975, at 106; O'Connell, Proposed: "No-Faull" Insurance to Stem Malpractice Suits, PrISM 12 (July 1974); O'Connell, Elective No-Fault Liability By Contract-With or Without an Enabling Statute, 1975 U. ILL. L.F. 59. See also Calabresi, Optimal Deterrence and Accidents, 84 YALE L.J. 656 (1975).

However, many influential groups, such as the American Hospital Association and the Massachusetts Bar Association, oppose the concept of no-fault malpractice insurance. 11 Hosp. WeEk, Apr. 11, 1975, at 1; Kickham, President's Message, 15 Mass. B. Ass'N NeWS LeTTER 2 (Apr. 1975). 
the defendant was at fault, and if so, what compensation he must pay for the injury. The formula for determining whether the physician is liable to the patient is commonly phrased in terms of his failure either to "possess the degree of professional learning, skill and ability which others similarly situated ordinarily possess," or to "exercise reasonable care and diligence in the application of his knowledge and skill to the patient's case."

Medical malpractice litigation is not new. The first recorded case occurred in England in the thirteenth century, and one of the earliest suits in the United States took place in $1794 .^{3}$ By 1845 , physicians liad indicated their alarm at the increase in such claims. ${ }^{4}$ Alternatives to the jury trial were recommended, mainly by doctors. The Massachusetts Medical Society suggested liaving a disinterested physician adjudicate nualpractice clainis by patients. ${ }^{5}$ In 1872 , the American Medical Association recommended that in medical malpractice cases which required expert testimony, physicians be appoimted independent arbiters by the judge. ${ }^{\circ}$

Yet, in spite of this traditional concern over the tort liability systein by the medical profession, there was no needical malpractice "crisis" as we know it until well into the 1970s. ${ }^{7}$ Sickness was accepted by most people as a common occurrence. Medicime was a limited science and adverse results were often regarded as the expected outconie.

Since World War II the number of malpractice suits, in absolute numbers, has nicreased steadily. ${ }^{8}$ Even today, however, though the

2. Medical Malpractice: A Consideration of the Problem, 27 Health L. Bull. 1 (Nov. 1971).

3. Cross v. Guthrey, 2 Root 90 (Conn. 1794). See Gussow, Answers Can and Must Be Found To the Malpractice Situation, J. LEgal MED. 20 (Mar. 1975).

4. Burns, Malpractice Suits in American Medicine Before the Civil War, 43 BuLL. Hist. Med. 41, 52 (1969). There are no reliable statistics for the total number of medical malpractice actions initiated before the Civil War. Yet an early commentator stated that "legal prosecutions for malpractice in surgery occur so often that even a respectable surgeon may well fear for the results of his surgical practice." J. Elwell, A MedicoLegal Treatise on Malpractice and Medical Evidence, Comprising the Elements of MEDICAL JURISPRUDENCE 82 (1866). Indeed, it was beheved that some practitioners were stopping their surgical practices because of the threat of malpractice. Id. (1962).

5. D. Konold, A History of AMERICAN Medical Ethics: 1847-1912, at 50-51

6. Id.

7. By "crisis" we mean the inability of physicians to purchase malpractice insurance at reasonable premiums, and, in rare cases, the inability to purchase such insurance at any price. In the past, many doctors did not even bother to buy malpractice insurance, even though rates were low. Gussow, supra note 3.

8. For recent figures, see Malpractice in Focus: The Problem . . . And Soine Solutions 11, 12-13 (AMA source document prepared by editors of Prism, Aug. 1975). 
niedical malpractice situation in the United States is generally considered to be a critical problem, most physicians still go through their entire professional lives without being sued, and those who are sued, are rarely sued more than once. ${ }^{9}$ The majority of hospitals, regardless of

Many factors led to this increase. More people could afford to receive medical care and, therefore, the number of opportunities for something to happen which would lead to a malpractice claim increased. See Malpractice Insurance Plagues Numerous Physicians, Hospitals, 4 Washington Developments 1, 4 (Jan. 31, 1975). Most other factors directly involve the rise of the hospital as the center of complex health care delivery. Medical technology became increasingly complex and sophisticated. Porter, Consumer Is Making Demands As Malpractice Crisis Grows, Boston Herald American, May 28, 1975, at 14, col. 4. William Curran, professor of legal medicine at Harvard University, feels that most malpractice cases are the result of the inherent risks of modern medicine with its rapidly developing techniques. Malpractice: MD's Revolt, NEwsWEEK, June 9, 1975, at 63 . The general practitioner was replaced by the specialist, teams of physicians, and medical institutions. Auerbach, Specializing Intensifies Malpractice Rate Issue, Washington Post, May 12, 1975, at A2, col. 3. The center of inuch medical practice moved from the office and home to the clinic and hospital. Altman, The Complexities of Medical Practice and Malpractice, N.Y. Times, June 5, 1975, at 28 , col. 4. This resulted in more inpersonal care and a deterioration of the intimate doctor-patient relationship, thereby creating further misunderstanding and disharmony. Malpractice Cooperation Urged, 3 Health Lawyers News Rep. 1 (Apr. 1975). See also Neeson, Mysticism Lost, 232 J.A.M.A. 374 (1975); Ribicoff, Medical Malpractice: The Patient vs. The Physician, Trial 11 (Feb./Mar. 1970):

When the patient-physician "rapport" remains on a high level of competence and trust, most patients will ride out a bad result through much pain and suffering and expense without resort to a malpractice lawsuit. But when that "rapport" is inadequate in the beginning, and is permitted to deteriorate en route, a malpractice suit is likely to follow.

Most of the larger awards made in medical malpractice cases have been against hospitals. See, e.g., Niles v. San Rafael, Civil No. 624,337 (San Francisco Super. Ct., Feb. 5, 1973); Miadema v. Glendora Hosp., Civil No. - (Los Angeles Super. Ct., June 4, 1973); Stearns v. Park Ave. Hosp., Inc., Civil No. - (Pomona Super. Ct., May 1, 1973).

Simultaneously with these changes in the practice of medicine came a growing consumer movement in society. Fellers, When Lawyers and Doctors Clash, 2 BARRISTER 8 (Suminer 1975). The trend was for the public to seek compensation for all injuries, resulting in an increase in personal injury litigation. More lawyers entered the malpractice litigation field, making the retention of competent plaintiff's counsel easier. Waxman, Spiraling Costs: A Health Care Slide, Trial 23, 24 (May/June 1975). Finally, the interest of the media in medicine and its advances not only added to the public's knowledge, but often led to unrealistic expectations of a physician's ability. This has often been referred to as the "Marcus Welby syndrome." Altman, Doctors Told Unrealistic Hopes Add to the Malpractice Crisis, N.Y. Times, June 16, 1975, at 12, col. 4.

While currently available statistics are inadequate to determine for certain, it is entirely possible that the actual incidence of medical malpractice cases, im terms of doctorpatient and lospital-patient contacts, has remained relatively constant over the past two decades.

9. In 1970, medical malpractice claims were made for only one out of every 226,000 patient visits to doctors. Medical MaLPRACTICE Report 12. Although exact figures for 1975 are not presently available, even making the unlikely assumption that the mcidence of claims has more than doubled, it would still be only one out of every 
size, go through an entire year without having a single claim filed against them. ${ }^{10}$ Jury trials of these claims are also unusual, with fewer than one trial held for every ten claims resolved, ${ }^{11}$ and eighty percent of all jury verdicts are in favor of the physician-defendant. ${ }^{12}$

Nevertheless, the fear of being sued permeates the medical community, and has an impact on almost every facet of the system. It affects health care practices and forms of medical treatment, the distribution of health manpower, the modes of processing claims through the legal system, and the attitudes of the public toward the dehvery of health care and toward the doctor-patient relationship in particular. ${ }^{13}$ The main component is an insurance crisis in which, as in the automobile insurance controversy, the availability and cost of nedical malpractice imsurance is in a state of turmoil. ${ }^{14}$

100,000 patient visits. In 1974 , malpractice actions were pending against one out of every ten physicians. Malpractice In Focus, supra note 8, at 13.

10. Medical Malpractice Report 9, 12.

11. Rudov, Myers \& Mirabella, Medical Malpractice Insurance Claims Files Closed in 1970, in Medical Malpractice Report Appendix 1, 13.

12. See Auerbach, Malpractice: The Doctor's Dilemma, Washington Post, May 18, 1975 , at C3, col. 6. Most patients who are injured by malpractice never receive any compensation for their injury. Cerra, Malpractice Claims: Many Are Filed, But Few Are Paid, N.Y. Times, June $1,1975, \S 1$, at 46 , col. 4. There are many times more medical injuries than there are claims. Auerbach, supra, at C3, col. 2. Some estimates put the number of significant injuries from medical malpractice at 750,000 annually. Medical Self-Regulation and Malpractice, 293 NEw ENG. J. MED. 562 (1975). The patient is more likely to sue if his injury is severe and he has no other sources of financial assistance. Medical Malpractice Report 25. Because of the complex medical issues involved and court backlog, lawsuits last between two and six years, or two to three times longer than other personal injury cases. Id. at 10-11. During this extended period the injured party receives no money and yet is least able to bear the cost of his medical and rehabilitation bills.

13. See Bird, Three Views on Malpractice: Doctor, Lawyer, Patient, N.Y. Times, Apr. 23, 1975, at 47, col. 7.

14. Estimates of the rise in the cost of inalpractice insurance premiums in recent years have varied between 50 and 1,000 percent. Medical Malpractice Report 8-14. In 1960, the Secretary's Medical Malpractice Commission estimated the cost of professional liability coverage at $\$ 60$ million. Insurance industry estimates, which are usually conservative, suggest a total premium paid in 1975 of well over $\$ 1$ bilkon. Between 1960 and 1970, inalpractice insurance premiun volume for dentists rose 115.7 percent; for hospitals, 262 percent; for physicians other than surgeons, 540.8 percent; and for surgeons, 949.2 percent. Malpractice in Focus, supra note 8, at 20.

Other figures are equally revealing. A New York obstetrician had to pay $\$ 9,433$ in 1974 to keep himself adequately covered against lawsuits. A specialist in a high-risk field like neurosurgery had to pay $\$ 14,329$. Suing the Doctor, TIME, July 15,1974 , at 78. Some physicians have at times found it difficult to purchase any insurance, with a number of insurance companies leaving the medical malpractice business altogether. Malpractice Carrier Sails Away, MED. WorLd News, Mar. 24, 1975, at 23; Hendricks, What Your Next Malpractice Policy May Look Like, MED. Econ., Apr. 14, 1975, at 29; A.M.A. Moves to Enter the Insurance Field in the Malpractice Battle, N.Y. Times, 
Numerous critics place much of the blame for this situation on the tort liability system and recommend its abolition. ${ }^{15}$ Because of the tort system's current unpopularity, the impending passage of some form of national health insurance may be used as an excuse to eliminate it in medical cases. In an attempt to determine the effects of such a policy, this Article will examine the workability of the traditional tort liability systein to demonstrate that the aforementioned problems are not inherent to the system, but merely are the result of its current mode of application. Accordingly, the use or discontinuance of the tort system under national health insurance should rest not on hollow slogans, but on a careful examination of the system's coverage, cost, quality control, and consumer responsiveness.

\section{The TORT Liability SYSTEM}

Many aspects of the tort liability systein have been attacked as contributing to the malpractice crisis. Res ipsa loquitur, informed consent, statutes of limitations, ad damnum clauses, damages for pain and suffering, unlimited damages, and the contingent fee system have been the primary targets. It will be demonstrated in this section that none of these characteristics accounts for the current malpractice "crisis"they are only lightning rods in the storm of controversy surrounding this issue.

June 20, 1975, at 33, col. 4; Teledyne Says It Erred in Letting Unit Cover Medical Malpractice, Wall Street J., Feb. 19, 1975, at 19, col. 1-2.

Hospitals have experienced a similar increase. For example, annual malpractice premiums for Long Branch Memorial Hospital in California rose from $\$ 12,000$ in 1965 to $\$ 820,000$ in 1975. Malpractice Insurance Plagues Numerous Physicians, Hospitals, supra note 8 , at 4 . In 1969 , Massachusetts General Hospital paid $\$ 120,000$ for malpractice coverage. In the past year alone, the cost has risen from $\$ 300,000$ to $\$ 1,200,000$ for the same coverage. Comments of Dr. Thomas S. Durant, Assistant Director, Massachusetts General Hospital, at Conference, The Great Medical Malpractice Crisis of 1975, Harvard School of Public Health, May 1, 1975. According to the Department of Health, Education, and Welfare, hospitals pay about two-thirds of the $\$ 1$ billion annual cost of malpractice insurance premiums. The cost of this imsurance is necessarily passed on through fees and charges and is ultimately paid by the patient. Approximately fifty cents of the daily cost for every patient in the average hospital is for the hospital's malpractice insurance. But in California, premiums paid represent a $\$ 4.65$ additional charge per hospital bed every day. Malpractice Insurance Plagues Numerous Physicians, Hospitals, supra note 8, at 1. Hospitals in Massachusetts may be forced to increase their room rates by eight to ten dollars per day in order to pay for increased cost of malpractice insurance. Malpractice Crisis Stirs Concern, Boston Herald American, Apr. 7, 1975, at 3, col. 2.

15. A complete examination of the concept of "fault" in civil litigation is beyond the scope of this work and has been dealt with in detail in numerous other articles. See note 1 supra. 
Res ipsa is invoked under special circumstances to shift the burden of persuasion in a case from the plaintiff to the defendant. Three conditions must exist for the application of res ipsa. First, an injury of the kind which usually does not occur in the absence of negligence must have taken place. Second, the conduct or mechanism causing the injury must have been under the exclusive control of the defendant(s). Lastly, the plaintiff inust have been free of any contributory negligence. $^{10}$ A typical case is a sponge left inside the patient after surgery. With the growing availability of discovery methods, however, res ipsa loses inuch of its importance and can be viewed inerely as a general rule of circuinstantial evidence. Indeed, recent statistics show that it plays a part in fewer than fifteen percent of all medical malpractice cases that reach the appellate level. ${ }^{17}$

The doctrine of informed consent has also received much criticisin froin the medical community. ${ }^{18}$ This concept, which has its roots in late nineteenth and early twentieth century battery cases, simply states that before a patient is asked to consent to a treatment, procedure, or operation, the physician should be required to nnake certain disclosures. These disclosures include risks of death or serious disability, alternative treatunents, consequences of not undergoing any treatment, problenis of recuperation, and success rates. The medical arguments against this doctrine are essentially three: (1) this information will unduly frighten patients; (2) patients will not understand this information or it will take too long to explain in a way they can understand; and (3) this doctrime permits patients to sue physicians in the absence of any negligence in the performance of the treatment, procedure, or operation. Physicians have reacted veheinently to recent cases basing the amount of inforination that niust be disclosed on a legal rather than a medical community practice standard, and have urged in a number of states, such as New York, the enactment of legislation specifically designed to radically curtail the use of this doctrine in a malpractice action. ${ }^{19}$

All of the evidence, however, seems to point to the fact that a well-informed patient is the least likely to sue his physician, and that curtailment of information disclosure is likely to lead to unrealistic ex-

16. W. Prosser, HANDBOOK OF 'THE LAW OF ToRTS 214 (4th ed. 1971).

17. Dietz, Baird \& Berul, The Medical Malpractice Legal System, in Medical MaLPRACTICE REPORT Appendix 87, 128.

18. The concept was roundly condemned by former A.M.A. President Charles Hoffman in his dissent in the Secretary's Malpractice Report. Medical Malpractice RePORT 122.

19. N.Y. Pub. Health Law $\S 2805-d$ (McKinney Supp. 1975). See Trout, New York State Malpractice Legislation, J. LEGAL MED. 26 (July/Aug. 1975). 
pectations followed by suits alleging malpractice in the presence of a less than expected result. ${ }^{20}$ Thus, the elimination or weakening of this doctrine, while it will remove the few suits founded primarily on this cause of action, ${ }^{21}$ is likely to imcrease significantly patient distrust of physicians and therefore malpractice actions in general. Moreover, the doctrine that patients, not physicians, should have the ultimate decision regarding specific therapies is so important to both self-autonomy and rational decision making that no erosion of it should be permitted. Exceptions relating to emergencies and cases where the physician can document serious adverse patient effects resulting froin full disclosure should be strictly limited to prevent thein froin engulfing the rule of routine full disclosure.

Although each state estabhishes its own statute of limitations, the usual maximuin permissible interval for imitiating tort suits is within two years of the date of the tortious act. ${ }^{22}$ An extension is sometimes granted for medical malpractice actions when the act of neghigence is not apparent or is concealed by the negligent doctor, the most common exception being for foreign objects left within the patient's body after an operation. ${ }^{23}$ In such cases the statute of limitations begins to run when the patient knew or had reason to know of the mjury or negligent act. $^{24}$ For minors the statute of limitations for medical negligence is usually tolled until the individual attains the age of twenty-one, or eighteen in appropriate states. ${ }^{25}$ This extended capacity for minors has been the central target of attacks on the statutes, ${ }^{26}$ although a shortening of the two-year limit has been proposed as well. ${ }^{27}$

20. Annas, Avoiding Malpractice Suits Through the Use of Informed Consent, CurRent PRoblems IN Pediatrics (to be published Mar. 1976).

21. Probably less than ten percent of the suits fall within this category. Dietz, Baird \& Berul, supra note 17.

22. See, e.g., N.Y. Civ. Prac. LaW \& Rules $\$ 203$ (f) (McKinney 1972).

23. See Flanagan v. Mount Eden Gen. Hosp., 24 N.Y.2d 427, 248 N.E.2d 871, 301 N.Y.S.2d 23 (1969); N.Y. Crv. PraC. LAW \& Rules $\$ 214$-a (McKinney Supp. 1975).

24. "[W] here a foreign object is left in a patient's body during the course of a surgical operation, the period of limitations begins to run when the patient knows or had reason to know about the foreign object and the existence of the cause of action based upon its presence." Tramutola v. Bortone, 118 N.J. Super. 503, 513, 288 A.2d 863,868 (1972), rev'd in part on other grounds and modified in part on other grounds, 63 N.J. 9, 304 A.2d 197 (1973). In medical malpractice cases, the statute of limitations commences to run "from the time of discovery of a right of action," that is "when the patient knows or should know that he has suffered injury or damage." Waldman v. Rohrbaugh, 241 Md. 137, 145, 215 A.2d 825, 830 (1969).

25. See, e.g., N.J. Stat. ANN. ch. 2A, \$ 14-21 (1952). Cf. IND. ANn. STat. § 169.5-3-1 (Burns 1975), which limits infancy disability to age six, at which time the twoyear statute of limitations for tort actions begins to run.

26. See Welch, Medical Malpractice, 292 New ENG. J. Med. 1372, 1376 (1975).

27. A number of states have already altered the law to begin the statute of limita- 
The reasons for placing a time limit on the period during which suit may be filed are twofold: first, to prevent victims froin suing alleged wrongdoers long after nnemories and details have become obscured, or medical records lost, and second, to allow persons to reconstitute their lives and escape the ever-impending threat of a lawsuit. ${ }^{28}$ In addition, statutes of limitations aid insurance companies in predicting the extent of their losses for any period so that they can adjust premiums to cover payouts. ${ }^{29}$ The application of statutes of limitations in inalpractice cases, and particularly the tolled statute for minors, is often blamed for the high imsurance rates which nust be charged to cover the contingency of delayed losses. ${ }^{30}$

tions with occurrence of the incident. Several, including Indiana, Texas, and Michigan, have fixed the deadline at two years after the act for most claims. See note 25 supra. California is considering a change to three years after occurrence, Florida has established the deadline at four years, and Maryland and Illinois, anong others, have set the cutoff at five years. Hendricks, Your Malpractice Protection, MED. Econ., Sept. 29, 1975, at 105, 1.10. The American Medical Association has suggested the following:

Insofar as they are suspended during minority or until the injury is actually discovered the statutes should be rectified to the extent necessary to reduce the "long-tail" problem. Therefore, no action for damages for personal injury whether based on tort or breach of contract, should be brought against any provider of medical care, unless

(1) The action is coinmenced within two years after the date on which the act or oinission occurred (exposure) which is alleged to have caused the injury, or

(2) Thereafter within six months of the date on which the person injured or the clainant knew or reasonably should have known (discovery) of the existence of such personal injury, but

(3) In no event shall any such action for damages be commenced more than five years from the date on which occurred the act or omission which is alleged to have been the cause of the injury. Fellers, supra note 8, at 71-72.

28. Riddlesbarger v. Hartford Ins. Co., 74 U.S. (7 Wall.) 386, 390 (1868); W. Prosser, supra note 16 , at 144.

29. Golladay \& Smith, Who Shall Pay? An Analysis of the Malpractice Crisis, 6 Research \& ANalytic Research Series 3 (Center for Medical Sociology and Health Services Research, Health Economics Research Center, University of Wisconsin 1975). As one insurance official stated, "If you can't determine rates based on your lossesand its nearly inpossible in malpractice insurance-then you don't belong in the business." Ribicoff, supra note 8 , at 13.

30. A limitation of twenty-three years of age for minors may seem arbitrary. Such a lengthy time span during which a suit can be brought inevitably invites the chance that the medical treatinent of a child will be judged by the more advanced standards existing when suit is brought, regardless of the judicial cognizance and admonition to the jury of the time factor. Yet before a shorter period is selected, inquiry should be made as to whether there are any circumstances which would cause the negligent treatment of a child to be less likely to manifest itself than negligent care of an adult. For example, linitations on a child's ability to cominumicate effectively might suggest that a two year statute of limitations sloould not begin to run until children are old enough to understand their bodies and communicate a problem. However, ability to conmunicate appears too subjective a standard for establishment of a uniform age. A more relevant difference between children and adults is physical development. Using this criterion, a two year limitation period would not begin to run for children until the child's skeletal growth stopped (e.g., age thirteen in girls, age fifteen in boys, or age fourteen 
A statute of limitations of two years does not appear to produce unwarranted claims and does not seem unduly lengthy in light of the above policies. In fact, a shorter limitations period might induce many claims to be made-which would not have been substantiated after a lengthier lapse of time and investigation-in order to protect against the contingency that later pain or slow recovery was discovered to be due to negligent care.

Elimination of ad damnum clauses, the estimate made by the plaintiff in his complaint as to the amount of damages le has suffered, has been proposed in many "malpractice alleviation" statutes. ${ }^{31}$ These damage requests often substantially overstate the probable range of recovery in order to emphasize both the severity of the plaintiff's imjury and to set a bargaining position. Therefore, since they may not reasonably be related to actual dannages, their abolition should probably be encouraged. ${ }^{32}$ Placing some limitations on damages for pain and suffering, a subjective injury which requires some speculation by the jury, might also be warranted..$^{33}$

A ceiling on the amount of total damages which can be awarded in a particular case has also been proposed in numerous malpractice alleviation statutes. For example, an Indiana statute has limited personal liability for each individual physician to $\$ 100,000$, and total damages for the entire suit to $\$ 500,000$, with any damages exceeding $\$ 100,000$ to be paid from a reinsurance pool funded by premiums from all insurance carriers in the state. ${ }^{34}$ Such a ceiling might lielp to contain costs, but only at the expense of seriously injured patients. ${ }^{35}$ of course, with national health insurance paying all or at least the most

as a compromise). A skeletal growth limitation would be objective and it appears to correlate well with full manifestation of any negligent treatment upon minors.

31. Welch, supra note 26, at 1374. E.g., IND. ANN. Stat. \& 16-9.5-1-6 (Burns 1975) (eliminates the requirement of ad damnum clauses).

32. Dornette, Indiana Adopts Malpractice Legislation, 3 J. LEGAL MEd. 26, 27 (June 1975); Welch, supra note 26, at 1347. Abolition was also recommended by the Secretary's Commission on Medical Malpractice. Medical MaLPractice Report 38.

33. It slould be noted that this criticism of damage awards for pain and suffering is applicable to the entire tort liability system, and is not limited to medical malpractice cases.

34. Ind. Anv. Stat. $\$ 16-9.5-2-2$ (Burns 1975). See New Indiana Law Will Cut Negligence Suits, Improve Care, 17 PhYSICIAN's LEgAL BRIEF 1 (Fall 1975).

35. Another suggested way for relieving the financial burden on defendants of damage awards is to permit collateral sources of compensation to be used to mitigate the amount of the damages awarded. These include continuing sources of income, lealth and accident insurance, social security benefits, workmen's compensation, disability insurance, and the income tax treatment given the monetary award. See Hirsch, Malpractice Crisis: Fact or Fiction, 80 CASE \& COMMENT 3, 4 (July/Aug. 1975). 
expensive medical bills, as will be discussed later, ${ }^{36}$ the problem of suing in order to meet large medical bills will be eliminated.

Few lawyers handle medical malpractice cases on anything other than a contingent fee basis. ${ }^{37}$ This payment system is often cited as contributing to the rise in malpractice claims. ${ }^{38}$ Such a belief is contrary to both the theoretical and actual operation of the system. Patients bring malpractice suits, not lawyers. Blaming the legal profession for such suits is akin to blaming the fire department for arson. ${ }^{39}$ Contrary to encouraging the filing of malpractice suits, the contingent fee structure actually compels lawyers to screen out claims which are spurious or for which recovery appears less than probable, as well as to refuse claims for which damages would not amount to a sum sufficient to reimburse their expenses. ${ }^{40}$ Since the attorney, rather than the patient, bears the financial risk of losing the suit, he has no incentive to invest any time or money in a claim for which recovery appears doubtful. ${ }^{41}$ In addition, with the average fee rate approximately one third of recovery, many lawyers decline malpractice cases which will probably achieve settlements or awards of less than $\$ 10,000$ because the expected compensation for the amount of time expended is not seen as worthwhile. ${ }^{42}$ The threshold value for the acceptance of cases for which recovery is less than probable would, on the average, be higher. Thus, although the vast majority of malpractice claims have been found to have some merit, most are rejected by the lawyers to whom they are brought. ${ }^{43}$ This also means that only a small percent-

36. See notes 56-82 infra and accompanying text.

37. Under this system, a lawyer does not get paid for anything other than his expenses unless the suit is won, in which case he takes thirty to fifty percent of the award. Porter, Consumer Is Making Demands as Malpractice Crisis Grows, Boston Herald American, May 28, 1975, at 14, col. 3.

38. See Bloom, Malpractice-The Mess That Must Be Ended, 106 ReADeR's Digest 79 (Apr. 1975); Hirsch, supra note 35, at 3.

39. Annas, Don't Blame Lawyers for the Malpractice Mess!, AM. MEd. News, Mar. 3, 1975, at 8.

40. See Sharpe, Contingent Fee-Physician Protection, Trial 21 (Feb./Mar. 1970).

41. Id.

42. Contrary to encouraging the filing of malpractice suits, the contingent fee structure actually compels lawyers to screen out claims which are spurious or for which recovery appears less than probable, as well as to refuse claims for which damages would not amount to a sum sufficient to reimburse their expenses. See Dietz, Baird \& Berul, supra note 17 , at $113-20$.

43. A recent study showed that lawyers reject twenty-three percent of malpractice cases for economic reasons. Malpractice Cooperation Urged, supra note 8, at 2. However, another study found that a large segment of defendant and plaintiff lawyers believed the contingent fee system liad little impact on an attorney's decision not to take a malpractice case. Dietz, Baird \&: Berul, supra note 17, at 119. 
age of injured patients who seek legal help actually obtain it. ${ }^{44}$

Of course, when two malpractice claims with similar prospects of recovery compete for an attorney's time, the contingent fee structure, with its flat rate of reimbursement, may encourage acceptance of the more shocking and sensational case, since it has the greater likelihood of eliciting jury sympathy and, accordingly, a larger recovery. The sliding scale fee structure, in which the percentage fee decreases as the plaintiff's award mcreases, would eliminate the purely financial inducement to accept claims with potentially large awards and would eliminate the potential which the contingent fee system has for wiping out a substantial portion of the injured person's recovery. ${ }^{45}$ However, it should be noted that this redistribution of the recovery between the patient-plaintiff and the attorney would affect neither the size of the award, ${ }^{46}$ nor the volume of suits.

Considering the patient's choice of possible schemes for payment of counsel fees, patients with large potential recoveries might prefer a per diem rate if they were certain of recovery, but most persons would prefer the lawyer to bear the fimancial risk of losing a case. In this sense, the contingent fee system encourages the filing of more cases by permitting the poor and lower middle class patient to seek legal aid which he would never have been able to afford under a per diem payment scheme. Yet, as noted above, the contingent fee probably encourages only the filing of meritorious claims by these lower $\mathrm{m}$ come patients. In addition, the rise in the cost of malpractice suits here is comparable to that in Great Britain, although the contingent fee for attorneys is not employed there. ${ }^{47}$ The contingent fee, therefore, is not a major factor in the development of the medical malpractice problem, and its elimination would do hittle to solve the dilemma.

The present tort system is also blamed for "defensive medicine," the alteration of modes of medical practice for the sole purpose of avoidimg legal liability. ${ }^{48}$ The annual costs of such practices have been

44. See note 12 supra.

45. New Jersey was an early leader in this area. In 1971 it scaled contingency fees so that a lawyer could collect only about $\$ 27,000$ on a $\$ 100,000$ award or settlement, and no more than ten percent of amounts exceeding $\$ 100,000$. See Hendricks, supra note 27, at 113-14 (suggests limit on contingent attorney fees to fifteen percent on malpractice awards exceeding $\$ 100,000$ ).

46. This would only be true if the jury were not instructed as to the application of the sliding scale fee structure to the damage award.

47. Curran, The British Experience in Medical Malpractice: An Upward Trend, 288 NEw ENG. J. Med. 249 (1973).

48. Tort Law Criticized and Defended, in Medical Malpractice, A Discussion of Alternative Compensation and Quality Control Systems 2, 3 (D. McDonald ed. 
estimated at from $\$ 1$ to $\$ 7$ billion $^{49}$ - estimates that alone call the entire notion of defensive medicine into serious question. Moreover, those studies which have been done, although all in the emergency ward setting, indicate that based on professional standards too few, rather than too many, diagnostic tests are being performed..$^{50}$ At the present time all that can be said is that we do not know the extent to which "defensive medicine" is practiced, ${ }^{51}$ but we do know that much that poses as "defensive medicine," such as appropriate expert consultations and the keeping of better medical records, is in fact improved health care. ${ }^{52}$ The fact that it has been imposed by the tort system is an advantage rather than a disadvantage of the present system. Moreover, its existence demonstrates the ability of the present tort system to change physician behavior, something no other measure, such as continuing education or licensing examinations, has been able to accoinplish. ${ }^{63}$

The present tort systein may leave much to be desired, but the major arguments against it from the physician's perspective are unimpressive. ${ }^{54}$ Any modifications contemplated under national health insurance should aim at improving one or more of the following four measures of success without impinging on the others: effective qual-

1971); Graham, Malpractice Suits Rise, Lead Doctors to Treat Patients With Caution, Wall Street J., Jan. 8, 1971, at 1, col. 6. Under this definition all defensive inedicine is, of course, bad medical practice since it deviates from standard medical practice for non-medical considerations. Its impact may also be the opposite of what is hoped for, i.e. a physician may get sued for the adverse reactions from an unnecessary test or procedure he performed for "defensive" purposes.

49. Golladay \& Smith, supra note 29, at 4; Regier, The View From HEW on Federal Involvement in the Malpractice Situation, J. LEGAL MED. 19 (June 1975); Wolfe, The Real Victim, Trual 26, 30 (May/June 1975). See also Hassard, Change Tort System?: Pro, MED. World News, Sept. 8, 1975, at 60, 62.

50. Brook \& Appel, Quality-of-Care Assessment: Choosing a Method for Peer Review, 288 NEw ENG. J. MED. 1323 (1973); Brook \& Stevenson, Effectiveness of Patient Care in an Emergency Room, 283 INEw. ENG. J. MED. 904 (1970). These studies may also indicate, however, that all physicians are doing too many tests in the sense that most of the patients in these studies felt better no matter what the physicians did or did not do to them.

51. Bernzweig, Defensive Medicine, in Medical Malpractice Report Appendix 38, 38-40. But see Defensive Medicine? Doctors Say Yes!, TrLAL 65 (Mar./Apr. 1973).

52. Project, The Medical Malpractice Threat: A Study of Defensive Medicine, 1971 DUKE L.J. 939.

53. Even the imposition of national standards under national health insurance holds little promise for imcreased use of licensing as a means of quality control, since this method rarely ferrets out gross incompetence.

54. The general opinion anong lawyers seems to be that the tort system is preferable to any of the proposed alternatives. See Goldstein, Malpractice Claims, N.Y. Times, June 6, 1975, at 18, col. 1; Goldstein, Doctors Called Opposed to Rights, N.Y. Times, June 3, 1975, at 22, col. 1 . 
ity control, complete patient coverage, cost effectiveness, and responsiveness to the consumer-patient. ${ }^{65}$

\section{NATIONAL HeALth INSURANCE}

Assuming that some form of national health insurance will be implemented in the near future, ${ }^{56}$ the impact of such a new fiscal and delivery system of health services upon the health care system must be determined before assessing the role malpractice litigation should play. Although national health insurance is primarily aimed at financing medical care, with reduction of medical negligence only a secondary target, changes in the finance system will produce side-effects which will defimitely influence the current medical negligence problem. ${ }^{57}$ Cost, quality, and extent and duration of service are among the factors which will probably be affected by a national health imsurance program. ${ }^{58}$

The numerous national health insurance proposals, which run the gamut from merely imcreasing the funding of present programs to rede-

55. See Annas, Medical Malpractice: Are the Doctors Right?, TRIAL 59-63 (July 1974). For an overview of what the states are doing to solve the medical malpractice problen, see Malpractice in Focus, supra note 8, at 30. One or more inalpractice bills have been enacted into law this year in twenty-eight states, a total of seventy laws. 3 State Health Legislation Report (Oct. 1975); Comment, An Analysis of State Legislative Responses to the Medical Malpractice Crisis, 1975 DUKE IJJ. 1417.

56. It has been estimated that a national health insurance program could become law in 1977 or 1978, but that a two-and-a-half year "tooling-up" period would be required after the law is enacted and before benefits actually begin. National Health $\mathbf{l n}$ surance: Reassurance From the Left, MED. ECON., June 9, 1975, at 133. At the present time, there is a feeling among Congressional leaders that NHI must take a back seat to anti-recession measures. NHI Prospects Recede, 3 Healtr Lawyers News ReP. 1 (Feb. 1975). Yet Leonard Woodcock, President of the United Auto Workers, has predicted that NHI will becoine a key issue during the 1976 presidential election. The AHA Reaffirmed Its Support for H.R. I, 11 Hosp. WeER, Apr. 18. 1975. at 1.

57. For example, encouragement of group practice rather than individual practitioner provision of health services may further depersonalize the physician-patient relationship, resulting in less communication, less understanding and a greater willingness to blame the provider for adversities.

58. All national health insurance bills attempt to extend health service coverage, in terms of both population and benefits, at a tolerable cost to the consumer. The unpredictable occurrence of serious illness or injury, coupled with the prohibitively high cost of medical treatment and care, have compelled focus on potential means for distributing the uueven and uncertain costs of health care to nake it a manageable burden for consumers.

Subsumed under the cost and extended coverage objectives in many proposed plans are the goals of controlling the quality of inedical care; increasing the supply of medical personnel, including the development of new levels of medical personnel; improving facilities, such as the implenientation of new delivery systeins; and distributing resources to underserved areas to rectify supply-demand imbalances. 
signing the fiscal and delivery mechanisins, reveal the lack of a political and medical consensus on how best to provide universal comprehensive liealth care. While it is a definite oversiniplification, for our purposes ${ }^{59}$ the three basic approaches to national liealth insurance can be defined as follows: catastrophic coverage, subsidy-credit, and uniform-compreliensive. We will argue that only some form of the comprehensive approach is likely to have any inpact on the way medical care is currently delivered in this country, and consequently on any metlod of reimbursement for negligently-induced injuries within the health care system.

A. Catastrophic Coverage. The basic model for this type of coverage $^{00}$ provides that the entire anount of a family's medical bills will be paid after a certain level lias been reached (e.g., $\$ 1,500$ annually). The purpose is siniply to prevent people from having to sell their homes and completely rearrange their lives because of a serious illness in the family. A modification of this approach would base the anrount of the annual direct expense limit or "deductible" on the fan1ily's income. If low enough, the deductible would be zero; if higl, the deductible would be correspondingly large. ${ }^{61}$ The advantages of such a proposal would accrue to the poor in that the welfare-non-welfare distinction would be removed, and even low income families who currently do not qualify for Medicaid would be covered after only a minimal deductible expenditure. While this form of imsurance would probably have the effect of increasing demand, especially for out-patient services, it is unlikely that it would lave any other major impact on the current health care system since it will in no way change the manner in which liealth services are delivered, and thus the current tort systern would continue to serve the same function it presently does.

B. Subsidy-Credit Alternatives. These proposals currently out of favor, would give either subsidies or tax credits to individuals in order to purchase commercial health insurance. Their main purpose

59. Since the objective of this Article is to determine what role malpractice litigation should play under national health insurance, many important aspects of the insurance question which are irrelevant to this discussion, such as whether revenues for the various proposals derive from payroll taxes or general revenues, will not be treated.

60. All 1975 national health insurance bills protect against catastrophic illness or injury. However, the National Catastrophic Illness Act of 1975, H.R. 1373, 94th Cong., 1st Sess. (sponsored by Rep. Roe) and the Medical Expenses Tax Credit Act, H.R. 3328, 94th Cong., 1st Sess. (1975) (sponsored by Rep. Martin), S. 600, 94th Cong., 1st Sess. (1975) (sponsored by Sen. Brock) are confined to such protection.

61. For example, the deductible under the National Catastrophic Illness Act of 1975 is an amount $\$ 1,500$ less than adjusted gross income except for individuals or fanilies with adjusted gross incomes less than $\$ 2,000$. The deductible diminishes from $\$ 500$ at $\$ 2,000$ of adjusted gross income to zero at $\$ 1,000$ or less of incoine. H.R. 1373, 94th Cong., 1st Sess. $\$ 2015$ (b). 
is to replace Medicare and Medicaid and encourage all individuals to purchase their own insurance programs. Politically the plan is unattractive since Medicaid currently provides nore benefits than do commercial carriers, and the poor and middle class might not be persuaded to purchase commercial imsurance. Moreover, because these proposals rely on current forms of health imsurance, they imclude all of the weaknesses in the present system. They are essentially instruments to redistribute imcoine, and should be judged as attempts at welfare reform rather than improvements in health care insurance. In the unlikely event that such a program is adopted, however, the present tort system would have to be maintained since a plan of this type would inerely change the financing mechanism while leaving essentially the same system for dehivering health care.

C. Uniform Comprehensive Health Insurance. The fimal major category of health insurance, and the one most likely to prevail in the future, is comprehensive coverage for the entire population. ${ }^{62}$ The inajor differences between proposals of this type involve the amount of direct federal intervention in quality control, modes of health care dehvery, the utilization of deductibles, coinsurance premiums, and finally, the types of services which are not covered (e.g., dental, psychiatric, home health care).

Perhaps the most anbitious plan is Senator Kennedy's Health Security Act, ${ }^{63}$ which would require no deductibles or coinsurance payments by the patient and would cover all medically necessary health services if rendered by a qualified provider. ${ }^{64}$ Such providers would have to abide by certain quality control regulations, such as PSRO inonitoring of services. ${ }^{65}$ Institutions would have to maintain utilization review procedures, as well as other standards, to assure the medical necessity of operations, a medically adequate level of treatment and care, and the efficient use of health care facilities. ${ }^{66}$ Individual practition-

62. Four "comprehensive benefits" bills were introducted in 1975: (1) The Health Security Act, S. 3, 94th Cong., 1st Sess. (sponsored by Sen. Kennedy and AFL-CIO Committee on National Health Insurance), H.R. 21, 94th Cong., 1st Sess. (sponsored by Rep. Corman); (2) National Comprehensive Health Benefits Act of 1975, H.R. 2050, 94th Cong., 1st Sess. (sponsored by Rep. Staggers); (3) National Health Care Services Reorganization and Financing Act, H.R. 1, 94th Cong., 1st Sess. (sponsored by Rep. Ullman and The American Hospital Association); (4) National Health Care Act of 1975, S. 1438, 94th Cong., 1st Sess. (sponsored by Sen. McIntyre and the Health Insurance Association of America), H.R. 5990, 94th Cong., 1st Sess. (sponsored by Rep. Burleson).

63. S. 3, 94th Cong., 1st Sess. (1975), H.R. 21, 94th Cong., 1st Sess. (1975).

64. Id. § 21.

65. Id. $\S \S 41,141,145$.

66. Id. $\S \S 43,51$. 
ers would be subject to continuing education requirements. ${ }^{67}$ Treatment by a qualified specialist and, except in an emergency, referral from a general practitioner would be prerequisites of reimbursement for major surgery and other special operations. ${ }^{68}$

Financial imducements, either educational loan forgiveness or income supplements, would be used to redistribute health personnel to the underserved rural and inner city areas. ${ }^{69}$ Development of more efficacious delivery systeins would be concentrated in attempts to stimulate the growth of Health Maintenance Organizations (HMOs).$^{\mathbf{7 0}}$

Less radical than the Health Security Act are national health insurance proposals which share the cost of benefits with the patient and gradually adopt comprehensive coverage over a period of years. ${ }^{71}$ Costsharing and graduated coverage are attempts to limit the demand expected from national health insurance. ${ }^{72}$

67. Id. $\$ 142$.

68. Id. $\S 143$.

69. Id. $\S \S 103,105$.

70. Id. $\$ \S 103(\mathrm{a}), 104(\mathrm{a})$. HMOs are prepaid group practice organizations which offer comprehensive health services either through their own facilities and staff or by referral of their enrolled members to outside sub-contracted facilities and personnel on a continuous 24-hour basis. HMOs have been able to provide comprehensive services to their members at a fraction of the cost spent in the non-organized delivery sector. The reasons postulated include: (1) better bealth status (fewer acute problems) among their members due to emphasis upon primary or preventive care, and health education of their members; (2) economies of scale, especially in administrative and record-keeping; (3) lower hospitalization rates because of (a) primary care and (b) a built-in fiscal inccntive to utilize the best, yet most efficient, treatments and resources. Quality care is maintained by competition among HMOs and the threat of malpractice litigation. The fiscal incentive has two facets: (1) governmental reimbursement for services on the basis of a prospectively-approved budget, and (2) compensation from members on a prepaid per capita basis rather than fees for services rendered. The only two factors that counterbalance tbe interest of the HMO staff iu cost-efficiency are malpractice suits and competition between HMOs which is non-existent today. See generally Bovbjerg, The Medical Malpractice Standard of Care Required of HMO Practitioners, 1975 DURE L.J. 1375.

Under the Health Security Act, HMOs can receive grants or loans for planning and construction costs, or expansion costs, and can be subsidized in toto for operating deficits incurred during the first five years, S. 3, 94th Cong., 1st Sess. $\$ \$ 103$, 104, especially helpful sinee HMOs do not reach economies of scale until their enrollments approach 30,000 , which may not be accessible within the initial years of growth. Other competitive advantages for HMOs would be broader drug coverage and broader psychiatric coverage for HMO enrollees than for patients of solo practitioners. Id. $\$ \S 22,25$. Supplementing HMOs with seventy-five percent of the differential between their actual institutional (hospital and nursing home only) care costs and the average institutional care costs for non-HMO-enrolled persons would be a special incentive to operate efficiently. Id. $\$ 87$.

71. H.R. 2050, 94th Cong., 1st Sess. (1975); H.R. 1, 94th Cong., 1st Sess. (1975); H.R. 5990, 94th Cong., 1st Sess. (1975); S. 1438, 94th Cong., 1st Sess. (1975).

72. For cxample, under the National Health Care Act of 1975, S. 1438, 94th Cong., 
The implementation of utilization review procedures at health care institutions is the primary quality control under all of these types of proposals. $^{73}$ The Health Care Act, for example, makes utilization review a condition of reimbursement for comprehensive ambulatory care centers and of approval of rates by the state, which is necessary in order to obtain federal cost-sharing. ${ }^{74}$ In addition to utilization review procedures, HMOs and Health Care Corporations. $(\mathrm{HCCs})^{75}$ must implement in-service training programs and must provide for the continued professional education of their staff. ${ }^{78}$ The Health Care Services Act explicitly orders each HCC to review annually the qualifications and on-the-job performance of every individual practitioner who has contracted with the HCC in order to determine the range of treatment and procedures he is competent to perform. ${ }^{7 \tau}$

The expansion of preventive and ambulatory health care is also stressed throughout all of the bills. ${ }^{78}$ Health maintenance measures, such as periodic checkups and immunizations, are fully covered without copayments under the Health Care Services and Comprehensive Benefits Acts. ${ }^{79}$ Each bill also encourages, through technical and financial supports, the development of comprehensive ainbulatory care centers or prepaid group practice organizations (HCCs and HMOs), which are designed to provide medical services and preventive care

1st Sess., H.R. 5990, 94th Cong., 1st Sess., a broad spectrum of benefits, similar to the comprehensive benefits of the Health Security Act, S. 3, 94th Cong., 1st Sess., H.R. 21, 94th Cong., 1st Sess. (1975), is to be established in two installments encompassing ten years. A flat deductible of $\$ 100$ would have to be satisfied before the insurance plan would reimburse providers for eighty percent of a patient's medical bill (i.e., twenty percent coinsurance rate). S. 1438, 94th Cong., 1st Sess. $\$ 501$. Total coverage, suspension of copayments, day limits, and consultation limits, is attamed when medical expenses reach ten times the apphicable deductible amount, or $\$ 1,000$ for all persons except those over sixty-five or with low incomes who enjoy subsidized deductibles. Id. $\S \S 501$, 531.

73. S. 3, 94th Cong., 1st Sess. $\$ 51$ (1975); H.R. 5990, 94th Cong., 1st Sess. $\$ 308$ (1975); H.R. 1, 94th Cong., 1st Sess. $\$ 244$ (a) (1975); H.R. 2050, 94th Cong., 1st Sess. \$ 1701 (1975).

74. H.R. 5990, 94th Cong., 1st Sess. $\$ \$ 308,531$ (1975).

75. HCCs, established under the National Health Care Services Reorganization and Financimg Act, operate and function similarly to HMOs. See note 70 supra.

76. H.R. 2050, 94th Cong., 1st Sess. \$§ 1701, 1758 (1975); H.R. 1, 94th Cong., 1st Sess. $§ \S 244(a), 245$ (1975); S. 3, 94th Cong., 1st Sess. $\S \S 131,142$ (1975).

77. H.R. 1, 94th Cong., 1st Sess. $\$ 245$ (1975).

78. S. 3, 94th Cong., 1st Sess. $\S \S 103$ (a), 47(a)(6) (1975); H.R. 1, 94th Cong., 1st Sess. § 2(C) (1975); H.R. 2050, 94th Cong., 1st Sess. $\S \S 2(b)(1), 1701$ (1975); H.R. 5990, 94th Cong., 1st Sess. \$\$ 301, 308 (1975).

79. H.R. 2050, 94th Cong., 1st Sess. $\S 1712$ (1975); H.R. 1, 94th Cong., 1st Sess. $\S 122(1975)$. 
programs more efficaciously than the traditional health care delivery system. $^{80}$

Comprehensive coverage of all essential liealth services would place great demand and stress upon the present health care delivery system. One study has estimated that comprehensive coverage, as under the Health Security Act, would increase demand for ambulatory care thirty to seventy-five percent, while requests for other, formerly uninsured services, e.g., prescription drugs and dental care, might be expected to increase at an even steeper rate. ${ }^{81}$ Utilization of hospital services under full coverage has been predicted to grow a "modest" ten percent since most persons are already covered by insurance that includes hospitalization benefits. ${ }^{82}$

80. S. 3, 94th Cong., 1st Sess. $\$ \S 103$ et seq. (1975); H.R. 1, 94th Cong., 1st Sess. $\S \S 218$ et seq. (1975); H.R. 2050, 94th Cong., 1st Sess. \$ 1745 (1975); H.R. 5990, 94th Cong., 1st Sess. $\$ \S 301$ et seq. (1975). To insure a competitive edge for the development of HMOs and HCCs, the federal government would subsidize ten percent of the premiums of persons who enroll with HMOs or register with HCCs. H.R. 2050, 94th Cong., 1st Sess. § 1722(c) (1975); H.R. 1, 94th Cong., 1st Sess. § 102(C) (1975).

81. Newhouse, Phelps \& Schwartz, Policy Options and the Impact of National Health Insurance, 290 NEW ENG. J. MED. 1345, 1346 (1974). This estimate is, however, seen by some critics as a slight exaggeration, since persons in poor health, with low incomes and low time values, would constitute a disproportionate share of those who currently lack coverage of outpatient services prior to national health insurance. Low income persons spend less on medical care than others, but this factor is negated when third parties pay all or most of the medical expenses. Low time value (i.e., waiting or travel time would not deter visits by the unemployed or salaried, as it would the "timepoor professional, executive or self-employed") and poor health would result in greater usage of ambulatory care facilities among the newly-covered than among others. Id. at 1347; Sparer \& Anderson, Utilization and Cost Experience of Low-Income Families in Four Prepaid Group Practice Plans, 289 New ENG. J. MED. 67, 69, 72 (1973). But see Greenlick, Comparing the Use of Medical Care Services By a Medically Indigent and a General Membership Population in a Comprehensive Prepaid Group Practice Program, 10 MED. CARE 187 (1972). Adding a deductible or coinsurance feature would only serve to deny treatment to those who inight need it most.

82. Newhouse, Phelps \& Schwartz, supra note 81, at 1345. The HMO prepayment scheme, whereby a member prepays an annual fee and in return receives a comprehensive range of health care services (with nominal charges for certain visits and treatments), encourages the HMO staff to keep hospitalization at a minimum. See MacLeod \& Prussin, Continuing Evolution of Health Maintenance Organizations, 288 NEw ENG. J. MED. 439 (1973); Note, The Role of Prepaid Group Practice in Relieving the Medical Care Crisis, 84 HARv. L. Rev. 887, 921-27 (1971). One study found significant increases in inpatient service demand as well as ambulatory care demand. Broida, Lerner, Lohrenz, et al., Impact of Membership in an Enrolled, Prepaid Population on Utilization of Health Services in Group Practices, 292 NEw ENG. J. MEd. 780, 782-83 (1975). The conclusions of this study are suspect, however, due to the fact that participating physicians were salaried before joining the HMO, rather than operating on fees for service. In addition, any initial study is suspect because increased checkups and ambulatory care will reveal acute problems ignored at first. 


\section{Impact of National Health Insurance Upon Medical Negligence}

While they may be viewed only as negotiating positions, provisions directed specifically at the medical malpractice problem are contained in each of the national health insurance comprehensive coverage proposals. The Health Care Act and the Health Security Act would preclude recovery in malpractice awards for expenses of treatment and rehabilitative care covered under a qualified health insurance policy or under the Act, respectively. ${ }^{83}$ Neither the Comprehensive Benefits Act nor the Health Care Services Act explicitly excludes such excessive recovery. The latter, however, does provide for internal grievance procedures and hearings concerning monetary claims of patients against providers. ${ }^{84}$

National health insurance may also be able to play a preventive role in medical negligence. Analysis of the incidence of malpractice claims reveals discrimination among geographical regions and between medical specialties. Health care practitioners in urban areas, especially surgeons, incur more malpractice claims, ${ }^{85}$ and consequently pay higher imsurance premiums, than their rural counterparts. Concomitantly, urban areas are relatively overserved by health care practitioners, especially dentists and surgeons, althougl not by hospitals, as compared with less populated areas of the Umited States. ${ }^{86}$ A more plaintiff-oriented legal climate and more alert consumerism among urban populations may account for the difference. The general tendency of rural populations to be treated by the local general practitioner with whom the family has had experience and developed trust over the years may also account for fewer malpractice claims in less populated areas, as does the fact that many residents of rural commumities go to specialists in urban areas for the type of sophisticated medical care which often forms the basis for possible malpractice actions.

Whether overrepresentation of practitioners, the presence of more

83. H.R. 5990, 94th Cong., 1st Sess. $§ 501$ (a) (1975); S. 3, 94th Cong., 1st Sess. $\S 54(1975)$.

84. H.R. 2050, 94th Cong., 1st Sess. §§ 1745(a)(9), 1757(b) (1975); H.R. 1, 94th Cong., 1st Sess. $\$ 236$ (1975).

85. Specialists are sued most often. Almost sixty percent of the malpractice suits filed in 1970 involved surgeons. Averbach, Specializing Intensifies Malpractice Rate Issue, Washington Post, May 12, 1975, at A2, col. 1. Indeed, a recent study involving forty-four states reported that one out of every seven general surgeons is facing a malpractice complaint. Malpractice: $R x$ for a Crisis, TIME, June 16, 1975, at 49.

86. Kendall \& Haldi, The Medical Malpractice Insurance Market, in Medical MaLPRACTICE REPORT Appendix 494, 524-29. 
specialists as opposed to general practitioners, ${ }^{87}$ or the performance of more surgery is responsible for the greater incidence of inalpractice claims in the urban sector, most national health insurance proposals will help to alleviate the situation. All of the "comprehensive benefits" bills provide financial imcentives to help redistribute health care personnel to the underserviced areas of the United States. ${ }^{88}$ The bills also promote the development of ambulatory care centers or HMOs. ${ }^{89} \mathrm{Em}$ phasis upon ambulatory and periodic preventive care will serve to alleviate the gap in patient-doctor rapport. Development of new levels of health care personnel, such as ambulatory care practitioners, may restore a type of health care provider with whom the patient can mamtain a continuing relationship. In addition, association with an HMO for all health services may facilitate rapport between the patient and practitioner when specialty treatments or operations must be undergone. Receiving specialist care through an HMO with whom one has had regular contact will foster more understanding, if only because of familiarity with administrative routimes, than if the patient had been referred to an "outside" specialist. At the same time, however, group practice delivery of health care, with its centralized administration of services, could imcrease the bureaucratization and assembly-line approach to providing health care. ${ }^{90}$ Alienation of patient trust and rapport might continue, calling for a new level of health care personnel devoted primarily to communicating with the patient, informing him of his rights, and restoring confidence in the health care provider.

National health insurance does not specifically address itself to malpractice premium rates, although it does suggest the possibility of governmental regulation. Under all of the "comprehensive benefits" bills, private health insurers must maintam an "acceptable" ratio of premiums collected to benefits paid out. Such regulation of malpractice rates appears likely if private insurers are not excluded altogether

87. Overall, there are twice as many surgeons in proportion to the United States population as there are in England and Wales; Americans also undergo twice as many operations as Britons do. How Good Is Your Doctor?, Newsweex, Dec. 23, 1974, at 46, 48. See also Bunker, Surgical Manpower: A Comparison of Operations and Surgeons in the United States and in England and Wales, 282 NEw ENG. J. MED. 135 (1970).

88. S. 3, 94th Cong., 1st Sess. $\S \S 103,105$ (1975); H.R. 5990, 94th Cong., 1st Sess. $\S \S 201,202,204$ (1975).

89. See note 70 supra. According to recent government statistics, there are 173 HMO plans serving over 5,700,000 people. Owens, Where You Fit in With HMOs, MED. ECON., Sept. 28, 1975, at 48.

90. See Mechanic, The Organization of Medical Practice and Practice Orientations Among Plyysicians in Prepaid and Nonprepaid Primary Care Settings, 13 MED. CARE 189 (1975). 
from the health insurance field. Equalization of insurance rates on a national or regional basis, or governmental subsidization of malpractice premiums, would destroy much of the financial imduceinent for a doctor to improve his own standard of practice. It would also decrease the incentive among the medical profession to police its own ranks. On the other hand, physician-owned insurance companies might provide strong fimancial incentives for peer review within the policy holder group.

Large-scale organization of the medical profession into local prepaid group practices, as promoted by most national health imsurance "comprehensive benefits" bills, could likewise provide a solution. Medical negligence could be insured against either by the group practice or by private insurers, with the group practice as the unit of adjustment. Withm the group practice, premiums could be prorated as a percentage of salary, or paid as an operating expense of the group practice. This arrangement could create an incentive on the part of the group practice to discipline its nembers and minimize malpractice. ${ }^{91}$

91. Individual staff members could be induced to improve their standard of practice by profit-sharing plans among the group members, and in the group practice through compulsory education, restriction of privileges and income, or expulsion. Strong peer review with effective sanctions would be essential, because group insurance will blunt the financial incentive to practice with care which is generated when the individual is wholly responsible for the cost of malpractice insurance.

Making the group practice the unit of adjustment for insurance rates, rather than the individual practitioner, rectifies two unwarranted disparities in current malpractice premium rates. First, rate differentials between inedical specialties would be largely eliminated, and second, rehef would become available for those practitioners who do not practice full time yet presently pay rates comparable to those who do, e.g., teachers and "the retiring." While it may be argued that those practitioners who practice less than full time are more likely to commit mistakes, the necessity of training practitioners and the "phasing out" of practitioners' careers probably warrants granting pro rata concessions in rates. Premium differentials between general practitioners and specialists, e.g., between orthopedic and general surgeons, are not warranted by questions of competency. Many factors other than general competency account for the disparities. Foremost among such factors is the lack of past acquaintance, present coinmumication and general rapport between specialists and patients. Unlike the family doctor with whom the patient periodically discusses his problems, the specialist is an unknown who often treats the patient in the impersonal confines of an operating room and who often only briefly communicates with the patient. New York's Special Problems, MEd. Wordd News, Feb. 24,1975 , at 25 . The rapport and trust which a general practitioner enjoys with his patients are seldom experienced by the specialist. Another factor is the type of treatment administered. The general practitioner usually indulges in minor treatments for minor ailments. The specialist, on the other hand, engages in more radical treatments involving complex procedures and sophisticated technology. The risk of some adversity, either an accident, negligent behavior, or unexpected complication, mcreases as the procedure becomes more complex and sophisticated. Kendall \& Haldi, supra note 86, at 588-90.

As long as all group practices provide a comprehensive range of services, including high-risk specialties, group practice rates most likely will be fair, will reheve high insur- 
While preventing some forms of negligence, national health insurance may simultaneously encourage defensive medicime in its worst form-unnecessary and potentially harmful tests and procedures. ${ }^{92} \mathrm{Al}$ though malpractice paranoia is blamed for overutilization of ancillary services and facilities, a want of cost controls and fiscal responsibility among health care provider's is probably at the root of the problem. ${ }^{93}$ Under the traditional fee-for-service system, the physician, who ordinarily makes the decision whether and by what mode to treat, passes his costs to the patient, and usually, beyond that, to the insurer. There is no financial incentive for the doctor to treat only when necessary and to utilize the most efficient method available. In fact, smce the doctor's income increases proportionately to his expenses, cost-saving is discouraged. To the extent that third parties, either governments or private insurers, cover the patient's bills, the patient also lacks incentives to save costs. National health insurance, by extending full coverage to the indigent and chronically ill, will exacerbate the lack of patient cost-consciousness.

Without financial incentives controlling the utilization of facilities and ancillary services, ${ }^{94}$ other factors influence volume and choice. For instance, the possibility of malpractice litigation compels the doctor to optimize chances for an acceptable outcome regardless of cost. The incentive to practice defensively is extremely strong because the costs of a malpractice suit to the provider, manifested in insurance premiums, reflect not only the value of the injury in terms of patient compensation, but also the costs of defining and measuring the injury, and the costs of shifting financial responsibility to the provider, i.e. legal fees and insurance admimistration costs. The ideal balancing of costs for optimum allocation of health care resources and optimum patient care would counterpose the benefits of utilizing additional services to gain more complete knowledge (im order to reduce the calculated risks of a procedure) against the costs of adverse outcomes. But the costs of adverse outcomes are grossly inflated under the present system because legal and insurance costs constitute a substantial portion of tort liability

ance costs for certain specialties, and will induce high levels of quality care through competition. If all or most services are not provided by group practices, federal subsidies will probably be necessary to sustain the independent provision of high-risk services.

92. See notes 48-53 supra and accompanying text.

93. See Project, supra note 52; Bernzweig, supra note 51, at 38-40; Freeborn, Determinants of Medical Care Utilization: Physicians' Use of Laboratory Services, 62 AM. J. Pub. Health 846, 852 (1972).

94. An extensive discussion of defensive medicine concluded that lack of cost constraints is the primary cause of overutilization of medical resources. See Project, supra note 52 . 
costs. Consequently, providers are economically compelled to practice defensively without efficient optimization of patient care. ${ }^{95}$ The stress which advances in medical research and education place upon the panoply of new diagnostic and therapeutic tools available to the physician also ignores costs. ${ }^{96}$ To redress this imbalance in cost consideration, health care practitioners must bear the financial risk of overuse of services. Prepaid group practices and utilization review procedures impose cost-consciousness upon their staffs as to choice of diagnostic and therapeutic approaches. Moreover, not only costs, but also deleterious effects, as from excessive radiations, must be considered. The malpractice suit rather than peer review would be more responsive to this latter concern. Conservative medicine, the avoidance of complex or specialty procedures because of the high incidence of complications, ijuries, and consequently, malpractice suits, is not wholly detrimental either. Limiting the practice of specialty procedures to specialty-certified practitioners, such as anaesthesiologists, who perform the particular procedures more frequently than general practitioners, and who have more of an incentive to keep informed on the latest discoveries concerning these procedures, will serve to miprove the quality of care delivered and will also reduce the need for confirmatory consultations. ${ }^{97}$ Yet, to the extent that malpractice concerns induce practioners to remain with the traditional, commonly-practiced methods of treatment, rather than try the latest, perhaps more effective, yet not commonly accepted approaches, conservative medicine may retard improvement in the quality of health care. ${ }^{98}$

\section{The EfFicacy of the Tort Liability System Under National Health INSURANCE}

In general, full health care coverage under one of the "comprehensive benefits" acts should reduce the number of malpractice suits, although without necessarily a corresponding reduction in the occurrence of inedical negligence. Those persons who suffer minor injuries

95. Golladay \& Smith, supra note 29 , at 8.

96. Childs \& Hunter, Non-Medical Factors Influencing Use of Diagnostic $X$-ray by Physicians, 10 Med. CARE 323 (1972).

97. The Health Security Act, S. 3, 94th Cong., 1st Sess. (1975), restricts coverage of specialty procedures to those operations performed by certified practitioners.

98. Witness the legal problems incurred by the innovator of the spinal jack operation, now commonly employed under the name of Harrington Rod, to correct scoliosis, referred to in the informed consent suit in Fiorentino v. Wenger, 26 App. Div. 2d 693, 272 N.Y.S.2d 557 (2d Dep't 1966); an appeal was taken by the liospital alone in Fiorentino v. Wenger, 19 N.Y.2d 407, 227 N.E.2d 296, 280 N.Y.S.2d 373 (1967); As will be argued later, PSROs may have the same effect. 
allegedly due to negligence and therefore require a small amount of additional medical care, such as a subsequent operation to remove a forgotten sponge, will probably not sue their health care provider since their insurance will cover the cost of the original and any additional medical care. None of the "comprehensive benefits" bills discusses this correctional care, but it would most likely be covered where medically necessary. When cosmetic surgery and other elective procedures would be appropriate to rectify any harm caused by medical negligence, the patient would have to recover against the medical personnel or institution at fault, since such nonessential care is not covered by national health insurance. Even thougli all "comprehensive benefits" bills, except the Health Security Act, demand twenty percent copayments for many charges, it is doubtful that this cost to the patient will have great impact in most cases. If the twenty percent charge becomes a significant cost to the patient, catastrophic coverage would be triggered, thereby eliminating any charge to the patient. Recovery for lost wages would still be received through a tort suit. The "catastrophic benefits" bills would reduce the number of malpractice suits by a lesser degree, since only extensive or very expensive correctional treatment would be covered by insurance. However, eliminating some of the "police" function that private malpractice suits perform will put additional strain on either internal or administrative regulatory procedures to check the occurrence of medical negligence.

However, to the extent that national health insurance coverage will eliminate direct payment of expensive medical bills, some small impact upon the overall malpractice problem should be expected, ${ }^{99}$ since the patient will only be likely to pursue the malpractice claim if a true injury has occurred, rather than because his total expenses appear oppressive.

The medical negligence problem must be handled by implementing procedures to improve the quality of medical care, designing a more efficient compensation system, and installing procedures to make the health care system more responsive to the consumer. Moreover, all this must be accomplished at a socially-acceptable cost.

A. Quality Control. Recognition that the medical malpractice insurance crisis has arisen because most suits are the result of actual inedical injuries often caused by neghigence, leads to the conclusion

99. It should be noted, however, that Britain, which has a nationalized health service in which medical costs are fully paid by the government, is experiencing a rise in malpractice suits comparable to that in the United States. Curran, supra note 47, at 252. 
that more effective quality control mechanisms are needed. The viability of the medical malpractice suit as one mechanism for regulating the quality of health care depends upon the ability of alternative procedures to perform the function with comparable efficacy. The essence of quality control is control by the person receiving services, so that in this sense the term is used to mean "aceountability." In addition to private policing by patient-victims through malpractice suits, ${ }^{100}$ possible vehicles for quality monitoring include internal policing by healthcare providers, and external policing by administrative agencies.

Regulation by an outside administrative body has never been attempted, and judging from analogous regulatory failures this method seems unattractive. ${ }^{101}$ Compared to the privately-initiated malpractice suit, peer review is also a poor substitute. Established peer review progranıs, such as utilization review committees and PSROs, lack the degree of adversity present in privately-initiated malpractice actions. ${ }^{102}$ Doctors and other health care providers are not motivated to discipline their peers by the monetary incentives that encourage patients to press malpractice claims. Professional pride is a limited incentive; while the desire to keep the stature of doctors and other medical practitioners at a high level may sometimes compel the elimination

100. See Roemer, Controlling and Promoting Quality in Medical Care, 35 LAW \& CONTEMP. PROB. 284, 297 (1970):

As a sort of last resort for quality control, one may consider the rights of the patient to sue the doctor or hospital or both for harm suffered from improper medical care. The exercise of this right has obviously been imcreasing in recent years, as patients-with the aid of lawyers-have become more aware of it, as the sanctity of the medical profession im the public eye has diminished, and as the courts have become more demanding of what may be expected of the average provider of medical service.

The Waxman Report of the California Assembly Select Committee on Medical Malpractice (June 1974) considered alternatives to the medical malpractice suit and found that

[w] hile there do exist quality control mechanisms within the government and medical establishment, these mechanisms are not sufficiently effective. At the present time, malpractice litigation is clearly the most significant external pressure prompting physicians to practice quality medicine. Cartwright, Change Tort System?: Con, MED. WorLd NEWs, Sept. 8, 1975, at 60, 64.

101. Administrative agencies also lack sufficient flexibility to momitor the rapidly changing standards of health care.

102. A preliminary inquiry is needed to determine what degree of adversity is optimal for ferreting out and preventing medical negligence. Since estimates show that the number of malpractice claims actually filed represents only a fraction of the potential claims possible for injuries due to participation in the health care system, Rudov, Myers \& Mirabella, supra note 11, at 13,20-21, the level of adversity manifested in malpractice claims appears less than optimal. The discontinuity of personal medical care needs supports the notion that patient adversity alone is insufficient for inducing improvement of health care services. The desire among discharged patients not to return to an institution for treatment, or undergo treatment for the same illness again, counters the incentive to sus in order to alter the procedures of a doctor or health care institution. 
of gross incompetency, the incentive is likely to wane when the deterrence of technical incompetency, such as not having kept abreast of the most recent and nost effective inedical procedures, is the objective.

Thus, in order to evaluate the adequacy of peer review programs, it is necessary to determme whether health care providers alone can attain at least the level of adversity generated through private medical malpractice suits. Group practices which operate on a profit-sharing basis offer a financial incentive for more extensive peer review coupled with more severe sanctions. ${ }^{103}$ All of the "comprehensive benefits" bills stress the expansion of the group practice mode of delivery. To the extent that the staff of an HMO is concerned with the financial viability of the organization or receives supplesnental imcorne according to a profit-sharing scheme, a financial incentive exists to scrutinize and discipline peers. However, group practice organizations usually compensate their staffs with an adequate base salary. This guarantee of a comfortable financial position inutes the incentive to discipline peers. ${ }^{104}$ Money supplements for continued professional education, expanding areas of expertise, or keeping the incidence of inedical injuries below a targeted level might raise the competency level of individual and institutional health care providers, but would not create the financial incentive to "beef up" peer review programs. Since the medical profession already enjoys the highest esteen among vocational roles, an appeal to professional pride will not necessarily produce intensified peer review and discipline. To date the strongest generators of peer review within health care institutions have been laws which condition funding or reimburseinent upon effective utilization review programs, ${ }^{105}$ and inalpractice suits holding loospitals liable for inadequate monitorimg of staff performance. ${ }^{106}$ Since it is doubtful that doctors will be provided with an incentive sufficient to lead them to discipline their peers, and since inalpractice awards provide a strong stimulus for health care institutions to scrutinize their staffs, it appears the private malpractice suit will still be necessary for inomitoring the quality of patient care.

In addition to these practical and historical considerations, it currently appears that the PSRO program is being impleinented in such a way as to encourage the use of additional inedical tests and proce-

103. See note 91 supra and accompanying text.

104. See Note, The Role of Prepaid Group Practice, supra note 82.

105. See, e.g., Pub. L. No. 92-603 (1972) (PSRO legislation).

106. See Darling v. Charlestown Community Mem. Hosp., 33 III. 2d 326, 211 N.E.2d 253 (1965), cert. denied, 383 U.S. 946 (1966) (case result caused changes in hospital procedure). 
dures with little or no regard for cost, ${ }^{107}$ and with no record of the effectiveness of the tests and procedures encouraged. ${ }^{108}$ As Professor Clark Havigluurst has concluded, "PSRO legislation alone does not supply the incentive needed to make PSROs achieve more than minor improvements over 'business as usual'."109

This leaves us with the private malpractice action. Not only does the system present a pervasive method of accountability for individual action, it also gives the patient a status more equal to that of the health care provider. The ability of the patient to bring a malpractice suit if he feels it warranted has a potentially great psychological value, as does the knowledge that a lay jury from the cominumity, rather than a panel of "defendant-sympathetic experts," will determine the outcome of the suit. Limiting quality momitoring to internal peer review control would increase suspicion about the best efforts of health care providers. ${ }^{110}$ Moreover, while malpractice litigation cannot substitute for more comprehensive systems of review (such as PSRO, PEP, or utilization review), ${ }^{111}$ it can serve to weed out the extremely incompetent and often dangerous practitioner that these systems either miss or perinit to continue to practice. ${ }^{112}$ Malpractice findings should also be routinely made available to licensing authorities so that removal or suspension of licenses can be undertaken where appropriate. To date only a few states have made attempts to "feed back" malpractice case

107. Havighurst \& Blumstein, Coping With Quality/Cost Trade-Offs in Medical Care: The Role of PSROs, 70 Nw. U.L. REv. 6 (1975).

108. See R. Carlson, The End of Medicine (1975); I. Ilitich, Medical Nemesis (1975).

109. Havighurst \& Blumstein, supra note 107 , at 68 .

110. This psychological need could be satisfied by allowing patients to instigate disciplinary proceedings against providers within peer review groups, although the feeling of impartiality emanating from a judicial determination would be compromised.

111. See Degenshein \& Ceccarelli, The End Result System, 292 New Eng. J. MEd. 704 (1975); Gonnella \& Zeleznik, Factors Involved in Comprehensive Patient Care Evaluation, 12 MEd. CARE 928 (1974); Grimm, Evaluation of Patient Care Protocol Use by Various Providers, 292 New ENG. J. MED. 507 (1975); Nelson, Relation Between Quality Assessment and Utilization Review in a Functioning PSRO, 292 NEw ENG. J. MED. 671 (1975); Williamson, Evaluating Quality of Patient Care, 218 J.A.M.A. 564 (1971). Complications are usually monitored as well as outcomes. Deviation from a selected tolerable range triggers a process review to determine whether certain procedures were carried out whenever a particular condition or complication was indicated. If the process analysis reveals that staff procedures were deficient, either new guidelines are promulgated or special education is imposed upon selected personnel. Process checklists, such as PEP, are utilized regularly by institutional staffs as guides for care.

112. One situation involved Dr. John Nork, a California surgeon, who over the course of a decade allegedly performed more than thirty unnecessary laminectomies that left many of his patients crippled for life. Gonzales v. Nork, Civil No. 228566 (Sacramento Super. Ct., Nov. 19, 1973). 
findings for quality control purposes. ${ }^{113}$ Wasting this source of extensive review of health care providers' performance seeins deplorable. ${ }^{114}$

Finally, the ultimate effect of a properly functioning tort systein would be to minimize the total number of injuries by giving those responsible for thein a financial (or other) incentive to reduce such injuries. This function is accomphished by at least two methods in inedical malpractice litigation: through insurance premiums and through a public trial. The premium impact can be minimized severely if physicians are permitted to pass on easily the increases in their rates to their patients, either directly or through third-party reimbursement. Under a system of national health insurance, it may also be appropriate for a federal agency to take over the malpractice insurance busimess altogether, and for the federal government under proper circunstances to pay a physician's entire malpractice premium. In these circumstances there would be little, if any, financial incentive to avoid sloppi-

113. See, e.g., Cal. Health \& SAFETY Code $\$ 1305$ (a) (West Supp. 1975):

Every insurer providing professional liability insurance to a health facility ... shall report . . . to the state department any final judgment over three thousand dollars $(\$ 3,000)$ rendered against such liealth facility $\ldots$ in, or any settlement over three thousand dollars $(\$ 3,000) \ldots$ of, a claim or action for damages for personal injuries caused by an error, omission, or negligence in the performance of its professional services, or by the performance of its professional services without consent.

See also IND. ANN. STAT. \& 16-9.5-6-2 (Burns 1975) (The "appropriate board of professional registration and examination" shall be apprised of the name of "every" health care provider (except lospitals) against who1n a judgment is rendered or settlement made so that the board inay review the "fitness of the health care provider to practice his profession.").

114. Stimeling, Information Feedback Might Avert Medical Mishaps, J. LEGAL MED. 29 (June 1975). It should be noted, however, that there are definite drawbacks to this method. Malpractice awards and settlements are poor indices of the need for disciplinary sanctions or education improvennents. Most malpractice cases are tried by juries whose non-expert findings cannot be readily or reliably interpreted to determine when to restrict privileges or impose educational requirements. Jury, and judicial, confusion of negligent or incompetent practice with unusual medical results, in particular, inakes thcir findings an inappropriate basis for imposing followup remedies. Malpractice settlements reflect considerations of time, cost, adverse publicity, and the possibility of losing before what are conceived to be plaintiff-sympatlizing juries, as well as strict issues of fault. Moreover, the size of jury awards and out-of-court settlements sometimes relate to the severity of the injury or the rarity of the result, rather than to the seriousness of the incompetent behavior. However, malpractice claims (after a medico-legal lay screening panel has eliminated the non-meritorious cases), settlements and awards could be used to trigger peer group investigations and the imposition of sanctions, although the time lag between the negligent act and the malpractice finding would diminish the effectiveness of such procedures. Reinedial education or disciplinary measures would then be recommended by health care providers reviewing the performance of their peers, depending upon whether negligence, gross incoinpetence, technical incompetence or lack of scientific understanding was responsible for the adverse result. Thus, malpractice findings alone are not effective data for these quality control purposes, but rather could be used to suppleinent the peer review requirements of national health insurance plans. 
ness. One way to retain such incentive, however, would be to include a deductible in all malpractice insurance policies that is sufficiently large to provide a fimancial incentive to avoid neghigence. Such a deductible could, for example, range from five to twenty-five thousand dollars, and could vary on the basis of income. It would not be recoupable through either increased fees or third party reimbursements. While deductibles have often been proposed as a way of preventing patients from abusing the health-care delivery systein through overuse, it is iromic that they are almost never mentioned as a way to prevent system abuse by providers. ${ }^{115}$ In addition, simce the vast inajority of medical malpractice suits are settled for much less than five thousand dollars, ${ }^{116}$ such a systein could also drastically reduce insurance pre1mums.

Insofar as a public trial is seen as distasteful to physicians and psychologically important to patients it should be retaimed to fulfill a deterrent role-both in encouraging physicians to avoid the necessity of experiencing it, and in assuring patients that it is available to thein if they are negligently injured.

B. Compensation for Injury. In addition to promoting quality health care, the tort liability system also compensates victims of medical negligence. While coverage under national health insurance will reheve part of this problem by removing most medical expenses froin the computation of damages, tort litigation would still seem to be necessary in order to allow the plaintiff-patient to recover the remaining elements which presently form the basis for compensation, sucl as lost wages, pain and suffering, and pumitive damages. Nevertheless, the medical malpractice liability system is a somewhat deficient compensating mecliamism. First, not all negligently caused injuries are compensated. To receive compensation, the patient-victim must at least be able and

115. The only example we have been able to find of the use of deductibles in medical malpractice is not entirely encouraging, however. In that instance an insurance executive noted that one of his insured physicians was paying an annual preminm of about $\$ 18,000$ a year, with a $\$ 2,500$ deductible per claim. He went on to note that he was "a superb doctor. His problem is that he handles an enormous patient load, makes at least $\$ 400,000$ a year and to do it successfully, he cuts corners. By doing this he has small malpractice claims which normally his deductible takes care of. He doesn't really damage people - he never cuts off the wrong leg or any of the other dreadful things you often read about. But he does have four to five claims a year." Barnett, Medical Malpractice Suits Vex, 318 J. Commerce, Nov. 27, 1973, at 2 (quoting K.C. Eberhard, executive vice-president, Signal-Imperial Insurance Group of Los Angeles). As this example illustrates, payment of a deductible may only encourage physicians to spread themselves even thinner, taking more patients than they may be able to adequately deal with in order to increase their gross income.

116. See Rudov, Myers \& Mirabella, supra note 11 , at 13. 
willing to sue the health care provider in a medical malpractice action. Legal counsel must be hired, medical testimony in some form (either textbook evidence or expert witnesses) must be available, and the patient-victim must be willing to expend time and commitment on a lengthy trial if an initial settlement is not forthcoming. Thus, only the most sensational and severe injuries are consistently pursued. ${ }^{117}$ Plaintiff lawyers estimate that they accept only one in eight clients who attempt to engage their services. ${ }^{118}$ While spurious claims may represent a substantial portion of those cases refused, many claims are rejected because the potential recovery is too low or it is too difficult to obtain sufficient evidence of medical negligence. ${ }^{119}$ Add to that figure the meritorious claims which the patient-victim does not pursue because he considers the cost and energy expenditure of litigation prohibitive, and the conclusion is that the medical malpractice liability system only compensates a small percentage of the victims of medical negligence.

Second, only a small percentage of the malpractice imsurance premiums paid by healtl care providers is received by patient-victims as compensation for their imjuries. Ideally, liealth care providers should bear the financial burden of negligent medical treatment, i.e. providers should directly reimburse patient-victims for the value of their losses due to negligently-caused injuries. Of course, in the final analysis, society as a whole always bears the financial burden of medical negligence througl1 increases in health care prices. However, under the present compensation system, almost eighty percent of liealth care provider premiums are allocated for legal and insurance costs. ${ }^{120}$ Such a large overhead seems grossly inefficient.

Third, the medical malpractice liability system sometimes confuses actual medical malpractice with injuries caused by presently unavoidable risks inherent to certain procedures, or not preventable because of imprecise medical knowledge. ${ }^{121}$ Patient-victims who liave incurred rare or unexpected injuries are often presuned by courts, and especially by juries, to have received negligent treatment. Unreasonable

117. See notes $37-43$ supra and accompanying text.

118. Dietz, Baird \& Berul, supra note 17, at 97.

119. See id. at 97-100.

120. See note 14 supra.

121. W. Prosser, supra note 16, at 228. See generally Wolfsmith v. Marsh, $51 \mathrm{Cal}$. 2d 832, 337 P.2d 70 (1959); Seneris v. Haas, 45 Cal. 2d 811, 827, 291 P.2d 915, 924 (1955); Rubsamen, Res Ipsa Loquitur in California Medical Malpractice Law-Expansion of a Doctrine to the Bursting Point, 14 STAN. L. Rev. 251, 270-80 (1962). 
public expectations that medicine can supply cures for all ailments have helped to foster such confusion. ${ }^{122}$

When it forces health care providers to insure patients against the calculated risk of an adverse outcome, malpractice liability imposes an unwarranted burden upon these providers and misallocates our limited health care resources. Yet, more troublesome than the financial burden, which the providers can pass on through higher fees, is the stigmatization of practitioners as negligent or incompetent because their patients incurred an unexpected counplication or outcome. Compensation for rare adverse results should not be sought through the tort liability systein unless the stigma of negligence and incompetence is carefully reserved for a true negligence finding, and is not associated solely with a compensation award for the plaintiff. However, divorcing these two concepts appears unlikely within the present tort liability system. For the reasons elaborated above, ${ }^{123}$ the tort liability system should be restricted to resolving allegations of medical negligence, with arbitration $^{124}$ and medico-legal screening panels ${ }^{125}$ supplementing the adjudi-

122. See Altman, Doctors Told, supra note 8.

123. See notes 100-22 supra and accompanying text.

124. Arbitration is a nongovernmental procedure for settlement of disputes between private parties. Parties to a dispute submit their differences to the judgment of an impartial party appointed either by mutual consent or statutory provision. Thus, the decision to arbitrate may be initiated by agreement of the parties or be imposed upon them. Both approaches are currently being used to a small extent for settlement of inalpractice disputes. Arbitration imposed by statute or by court decision is generally applied to disputes under a certain maximum amount, with the jury trial system preserved for the larger cases. See Bergen, Arbitration of Medical Liability, 211 J.A.M.A. 175, 176 (1970).

Proponents of arbitration inaintain that it lowers legal fees, allowing small claims and claims involving difficult evidentiary problems to be compensated. Legal costs are lowered because only a short time is permitted for case preparation, cross-examination is not allowed, and strict evidentiary rules are suspended, thereby allowing hearsay and other excludable evidence to be produced in order to establish a cause of action. In addition, the need for expert witnesses is diminished since the arbitration panel is usually composed of health care experts who are acceptable to both sides. See Averbach, $A$ Plaintiff's Attorney Says: Malpractice Cases Don't Belong in the Courts!, Hosp. PHYSICAAN 56 (Jan. 1969); Coulson, The Malpractice Mess: Is Arbitration the Answer?, 99 MEd. TIMEs 131 (Oct. 1971); Ludlain \& Hassard, Arbitration, 114 Cax. MEd. 102 (May 1971); Arbitration of Malpractice Claims, 28 ARUZ. Med. 391 (May 1971).

Where arbitration is final and binding, the same saving of costs holds true. Where appeal for a trial de novo is allowed, limitations can be placed upon the appeal procedure to restrain appeals and thereby effectuate a cost saving. The appellant, under appropriate circumstances, can be charged the costs of appeal and the appellee's legal fees, as well as be required to post a security bond guaranteeing the payment of appellate costs. Another possible restraint is the admission at trial of the arbitration panel's findings, either as presumptions or merely as evidence. Even when such cost and evidentiary restraints are not imposed upon the appeal process, arbitration should lessen the judicial 
cation process. Imposing arbitration for claims which probably would not result in profitable recoveries if fully litigated (e.g., below a

burden by discouraging those claims which cannot be proved even before the more permissive arbitration panel, with its relaxed evidentiary standards.

The availability of a prompt decision by arbitration may encourage early settlement of claims. For the health care provider there is the benefit of comparative privacy and an absence of public cross-examination. No transcript is required unless by party request, and the arbitrator's decisions are not published. Arbitration awards would probably attract less attention than jury awards, especially if the amounts were in accord with predetermined schedules. Arbitration of Malpractice Claims, supra, at 392.

Of course, the lack of publicity has negative consequences for quahty control, especially if transcripts and records are not made of the arbitration hearing. The feedback from malpractice cases that could be potentially harnessed for quality control purposes would be eliminated if arbitration panel hearings were not recorded. In general, the more subdued level of publicity would put greater pressure upon peer review and disciplinary measures to sustain the quality level of health care. Therefore, it should be recominended that arbitration findings be fully reported for quality control purposes. Reporting of arbitration findings could be aecomplished in two forms. One system could report findings sans nomina. Such reporting would locate problem areas or institutions needing intensified preventive programs against imjuries and negligence, yet at the same time not damage the reputations of individual practitioners. The alternative to this method, full disclosure of the names of practitioners found negligent, would exert pressure directly upon the individual practitioners to improve their health care practices.

Those who are critical of the use of arbitration to resolve malpractice claims contend that the major motivation behind establishing arbitration is to benefit hospitals, doctors, and the insurance industry, with hittle benefit for the patient. See The Case for Arbitration, in Medical Malpractice, supra note 48, at 8,12. They argue that the proposed advantages of speed and economy apply only to the hearing phase, since it neither reduces the overall time required for claim resolution nor economizes greatly the preparation phase.

It must be conceded that to the extent that arbitration attempts to resolve claims with finality, the costs of operation to the parties may well approach those of a judicial proceeding. Moreover, if the arbitration system employed is not binding on the parties, it may add yet another expensive stage to the current jury trial process. Cf. Baird, Munsterman \& Stevens, Alternatives to Litigation, I: Technical Analysis, in Medical MaLPRACTICE REPORT Appendix 214, 215 (present arbitration plans reduce court dockets by only $0.7 \%$ of the total volume of malpractice claims).

125. See Karcher, Malpractice Claims Against Doctors: New Jersey's Screening Procedure, 53 A.B.A.J. 328 (1967); Matte, A Neutral Screen, Trial 34 (Mar./Apr. 1973); Williams, Joint Medico-Legal Plon for Screening Medical Malpractice Cases, 96 VA. Med. Monthly 297 (1969); Are Malpractice Screening Panels the Answer?, MEd. EcoN., Mar. 1, 1971, at 106; Documentary Supplement, Medical-Legal Screening Panels as an Alternative Approach to Medical Malpractice Claims, 13 WM. \& MARY L. REv. 695 (1972). Indiana's scheme places three physicians and one non-voting lawyer-chairperson on the panel. Conspicuously absent is any consumer or patient-advocate representative. Ind. ANN. Stat. \& 16-9.5-9 (Burns 1975). See New Indiana Law Will Cut Negligence Suits, supra note 34.

Mandatory mediation panels have been employed recently in New York with positive results in decreasing the number of cases proceeding to trial and in reducing the amounts of compensation. The three-member mediation panels consist of a state suprene court justice, a lawyer, and a plysician. Parties may be represented by counsel, the hcarings are informal, and no stenographic record is kept. If the case proceeds to 
$\$ 10,000$ potential recovery threshold) would result in more equitable resolution of malpractice claims. Injured patients for whom the costs of malpractice litigation are prohibitive could receive a less costly, expedited decision as to whether malpractice was the cause, thereby making less seriously, yet negligently, mjured persons eligible for relief. Mandatory screening panels, through a preliminary opinion on the merits, could encourage settlements or abandonment of claims.

Following a determination of negligence by the appropriate adjudicative procedure, i.e. litigation, arbitration, and/or screening panel, a siniplified hearing before a regional panel of compensation experts could decide a value for the imjury, perhaps based in part on a compensation schedule. The panel could be composed of physicians, lawyers, insurance experts, and consumers, who would sit on the board for a staggered tenure of about three years, thereby allowing each member to become experienced in the field of compensation, yet without allowing any particular individual to become entrenched in an extremely powerful position. A sitting panel would probably reduce the arbitrariness of awards, be less susceptible to emotional pleas, and be more responsive to the actual damage value of the injury. Employment of a schedule of benefits as a base would also stabilize awards. The compensation schedule would originally be based on present medical malpractice awards and imsurance industry figures, but would be continually revised and updated based on actual panel experience in the area and changes in the community. It should be noted that the crucial factor which differentiates this scheme from a "no fault" system is that no compensation will be awarded by this panel unless a finding of negligence has been previously made through adjudicative means.

C. Responsiveness to Consumers. A major problem with large hospitals and HMOs is their increasing depersonalization. Health care administrators often overlook the fact that while medical personnel may be familiar with their institution's routine, most outsiders are not, and that this unfamiliarity can cause irritation and anxiety. Even under the best circumstances, being a patient in a hospital or in an HMO can make a person uncomfortable and can magnify his dissatisfaction with his medical treatment. ${ }^{126}$

trial, statements made in the course of the hearings are not admissible. Ragan, $\mathrm{A} \mathrm{Mal}$ practice Experiment in New York, 100 Med. TIMEs 23 (Feb. 1972). See AMA Malpractice Liability Plan Accents Risk Control of Doctors, Trual 5 (Sept./Oct. 1971); Lee, New Court Directions: The Medical Malpractice Mediation Program, 9 TraA LAWYERS Q. 86 (1973); Owens, Compulsory Malpractice Mediation: Don't Sell It Short, MED. EcoN., June 9, 1975, at 94, 99.

126. See Annas, supra note 20. 
The quality of the relationship between the patient and the health care provider, whether doctor, hospital, or HMO, may of course influence the patient's decision whether to file a malpractice suit. ${ }^{127}$ The health care provider's failure to recognize this fact often creates an atmosphere for future problens and complications to develop into a malpractice action. The claim itself is often merely the tangible evidence of the final breakdown of the patient-provider relationship. ${ }^{128}$

Numerous factors lead to this breakdown. Interpersonal problems between the provider and the patient may cause a dissolution of the necessary rapport during the course of therapy. Some physicians charge that lawyers and legal rules are at the base of the deterioration of the doctor-patient relationship. ${ }^{129}$ However, physicians are aware that they may be the cause of this problem. In one recent survey, forty percent of doctors responding named "poor communication between physicians and patient" as the single most common cause of malpractice suits. ${ }^{130}$ In many instances a genuine misunderstanding exists on one or both sides. The physician may believe that he has explained everything, but the patient may not have understood and may be fearful of asking questions. This problem is particularly acute witl those patients who belong to low-status classes in society. Physicians occupy a high status position, and status differentials in general are maintained and acknowledged by various forms of deference. Generally, the greater the social distance between the doctor and patient, the more reluctant the patient will be about questioning or confronting the physician.

There is a general need for more effective communication between physician and patient, particularly as to diagnosis, proposed course of treatment, and possible complications, smce these items have the most potential for malpractice litigation. In addition, changes in the type of care physicians render have aggravated the communications problem. Doctors have begun to spend more of their time with the acutely ill, performing such tasks as reading laboratory and x-ray reports, while devoting very little time to the "routinely" ill and their health care questions. Although this shift sharpens the physicians' technical skills, it dimimishes their reliance on physical examinations

127. See Kupers, It Takes More Than Insurance to Protect Against Malpractice Suits, J. LEGAL MED. 33 (Mar. 1975).

128. Bachman, Doctors: Move Closer to Your Patient!, Trial 25 (May/June 1975).

129. See Ferber \& Martin, New Prey for Ambulance Chasers?, Med. EcoN., Apr. 28, 1975, at 126; Quicksilver-Emotion and Fear, TrIaL 15 (May/June 1975).

130. Pabst, A Medical Opinion Survey of Physicians' Attitudes on Medical Malpractice, in Medical Malpractice Refort Appendix 83, 84. 
viders, on their part, liave done little or nothing to limit those expectations, preferring instead to enjoy the esteem and economic and social status of their position. ${ }^{136}$

The inedical malpractice crisis may, in fact, be due in large measure to the failure to recognize the liuman needs of patients, the professional limitations of providers, and the sliared responsibilities of meinbers of the community for the health of their fellow citizens. With rare exceptions, the tort liability system provides the only niechanisin by which patients who have, or think they have, suffered an injury as a result of negligent nedical treatment can obtain redress.

A nuniber of hospitals have recognized this problent, and have developed a system of "patient representatives" to help "humanize" the lospital atmosphere. This innovation followed a recommendation by the Report of the Secretary's Commission on Medical Malpractice that every hospital establish a patient grievance mechanisin. ${ }^{137}$ However, few of the approximately 350 systems presently functioning im hospitals as patient grievance mnechanisnis have adequate authority to deal with those problems which often lead to inalpractice claims. ${ }^{138}$ The job description of the patient service representatives instructs then to deal with non-nredical, non-fiscal, minor complaints of a public relations nature, thereby limiting these representatives to a cosnretic role in the patient care continuunt. ${ }^{139}$ Although many of these efforts are to be applauded, none operate on the niajor complaints which induce nialpractice suits, and therefore can provide only a nrarginal reduction in the incidence of such suits against health care institutions. ${ }^{140}$

This problem beconies more acute under a systeni of national health insurance, since the provision of health care services could well beconre increasingly institutionalized and impersonal. A recent survey of HMO officials revealed that many viewed the large organizational character of their facility as likely to make their patients nore willing to sue the HMO than they would be to sue a private practitioner. ${ }^{141}$

While the elimination of direct payments by the patient under a system of national health insurance will make care more available to

136. Altman, Doctors Told, supra note 8.

137. Medical Malpractice Report 84.

138. Profile of Patients' Rights and Hospital Patient Representatives, HzALTH PERSPECTIVES 3 (Feb./Mar. 1974).

139. According to the American Hospital Association, patient service representatives exist in 462 hospitals. Thompson, Lupton, Renck, et al., Patient Grievance Mechanisms in Health Care Institutions, in MEDICAL MALPRACTICE REPORT Appendix 758, 760.

140. See, e.g., Cote, The Patient's Link, Trial 28, 29 (Mar./Apr. 1973).

141. Curran \& Moseley, The Malpractice Experience of Health Maintenance Organizations, 70. Nw. U.L. REv. 69, 81 (1975). 
and history-taking - two important situations in which the patient has direct contact with a credible and responsible individual provider. ${ }^{131}$

Intimate rapport with patients is not only good medical practice, but is also a prime malpractice prophylactic. ${ }^{132}$ The interpersonal relationship between doctor and patient, rather than any technical or scientific achieveinent, often prevents a patient from suing his physician. It is interesting to note that in many states with a low incidence of malpractice litigation, such as Montana, New Hampshire, and Vermont, there are large numbers of rural communities in which close, personal relationships develop over the years between physician and patient. ${ }^{133}$ This pattern differs dramatically from the overall trend of an increasing percentage of health care being provided through neighborhood health chinics, HMOs, and outpatient departments of hospitals. Institutionalized medicine tends to be far more impersonal than care provided by a trusted family doctor, and many patients feel unable to make their needs and complaints effectively known in these settings. The shift toward institutionalized medicine accounts for the findings of a recent survey which demonstrated that most people felt that the doctor-patient relationship today is not as good as it was twenty years ago. ${ }^{134}$

Patients often have unreahstic expectations regarding the outcome of inedical treatment, based in part on misinformation. These patients will likely be disappointed, but some patient dissatisfaction might have been avoided had the doctors involved discovered the patient's expectations and, where necessary, attempted to redirect those expectations in more reahistic directions. Perhaps all patients have come to have expectations which are far out of proportion with reality. ${ }^{135}$ And pro-

131. Childs \& Hunter, Non-Medical Factors Influencing Use of Diagnostic $X$-Ray by Physicians, 10 MED. CARE 323 (1972); Donaldson \& London, Time Study of Doctors and Nurses at Two Swedish Health Care Centers, 9 MED. CARE 457 (1971); Freeborn, Determinants of Medical Care Utilization: Physicians Use of Laboratory Services, 62 Aм. J. Pub. Health 846 (1972); Hardwick, Clinical Styles and Motivation: A Study of Laboratory Test Use, 13 MED. CARE 397 (1975); Mechanic, General Medical Practice: Some Comparisons Between the Work of Primary Care Physicians in the United States and England and Wales, 10 MeD. CARE 402 (1972).

132. See How to Avoid Maipractice Suits, MED. WorLd News, Sept. 22, 1975, at 61, 62.

133. Giddings, Why the Malpractice Plague Is Passing Some States By, MED. Econ., May 26, 1975, at 37. See also Thurlow, Yes, There Is a Malpractice Paradise, MED. Econ., Jan. 18, 1971, at 142.

134. Peterson, Consumers Knowledge of and Attitudes Toward Medicai Malpractice, in Medical Malpractice Report Appendix 658.

135. Wilson, Doc Welby Wows Public, Gives Med Biz Shot in Head, Boston Sun. Globe, June 29, 1975, at A7, col. 2; Malpractice, Rx for a Crisis, supra note 85, at 4950. 
many, it also may make the provider less concerned about patient acceptance and attitudes than in a system in which the patient directly compensates the provider. It will therefore be necessary to build into the system some mechanism, at least at the hospital and HMO level, to help the patient exercise his legal rights and obtain all the information he needs about his medical condition, the health care facilities, the proposed treatment and its risks and benefits, alternative treatments, problems of recuperation, and staff qualifications. ${ }^{142}$ To perform this function, and simultaneously to decrease the number of malpractice suits prompted by impersonal attention, imadequate preparation for an adverse reaction or result, umecessary surgery, and poor physician-patient and staff-patient relationships, we propose the development of a national medico-legal office with representatives in every major hospital and HMO.

These representatives would work for the national health insurance system. This separation of the representatives from the health care institution is essential for the proper functioning of the mechanism. Each representative must know that his primary obligation is to provide assistance for the patient, and that his relationship with the hospital or other medical facility is not one of employer to employee. In this way the representative could feel free, when necessary, to oppose those decisions which the institution might think in its own best interest, without fear of financial repercussions.

Every member of the medico-legal office would be legally empowered to lielp patients exercise their legal rights to such things as full and complete medical information, consultations, treatment refusals, discharge delays, and transfer requests. ${ }^{143}$ In order to liave an adequate awareness of these rights and knowledge of the manner in whicl they function in the health care contimuum, it seems essential to have the persoimel of the office composed of individuals froin diverse disciplines, mcluding, but not limited to, representatives of law, medicine, social work, and psychology.

On the individual hospital or HMO level, there would be a separate medico-legal office, again staffed with similar persomiel who are in the employ of the national health imsurance system and not of the particular lealth care institution in which the specific office is located.

142. See Annas \& Healey, The Patient Rights Advocate: Redefining the DoctorPatient Relationship in the Hospital Context, 27 VAND. L. Rev. 243 (1974).

143. See generally G. ANNAS, The Rights of HosptTal Patients (1975); JoInT Comm. on Accreditation of Hospitals, Accreditation MaNual for Hospitals 1-2 (1973). 
These representatives would be available to help resolve patient-staff disputes at the facility level without resort to litigation. This function would include settlement attempts following the occurrence of a medico-legal problem, ${ }^{144}$ as well as efforts to prevent problems through early interaction with patients, ${ }^{145}$ and provider-patient education concerning applicable health law issues, particularly patients' rights. ${ }^{146}$ In addition, the representatives would collect data on the types of patient complaints that most often lead to malpractice actions, using this information as a basis for devising methods for preventing these problems in the future. Thus, the ultimate goal of a properly functioming medi-

144. This function would include categorization of common patient complaints, with notation of appropriate measures called for, and accompaniment of the patient by the representative throughout the in-hospital attempt at resolution. It could also include, assuming authority was received from the health facility's insurance carrier, settlement negotiations.

145. This could be accomplished in the following manner. Upon completion of registration for each patient, the clerk would page the patient representative to inform him of the patient's arrival. As soon as it is medically permissible, the representative would explain to the patient that if at any time during his visit, or a subsequent visit concerning a related complaint, he desires assistance in resolving any problems-such as billing, commumications with the provider, or medical care-he should ask to speak with the patient representative. It should be noted as well that the entire staff of the facility should be informed of the services of the medico-legal office and its personnel. In addition, they should be encouraged to call the office if any situation arises in which the patient desires assistance from the representative.

146. Provider-patient education programs might be developed in numerous ways. For example, there could be a mim-course, consisting of two sessions of two hours' duration, which would be required of the entire staff of the institution. These courses would include instruction in problems of communication (e.g., importance of clear communication, ways of documenting what has been communicated, common pitfalls in communication); recognition of medico-legal problems; the role and function of the medico-legal office personnel; the type of patient complaints received or anticipated; the procedures for handling specific problein situations; and several important legal principles, such as informed consent and access to medical records. A broader, nine-month seminar program could then be offered to the staff. Participation in this would be optional, but highly encouraged. Each session would meet for two hours a inonth. The inaterial to be covered would include medical decision-making; recognizing legal problems; clarifying communications with patients; compensation for personal injuries; professional liability; patient rights; rights and duties concerning emergency medical care; regulation of the medical profession; cooperation with law enforcemeut agencies; rights of the dying patient; and confidentiahty and privacy. Special medico-legal sessions could be designed and added for specialty groups, such as transplant surgeons and ancillary laboratory staff. In addition, office personnel could offer periodic seminars on medico-legal issues, as well as initiate the publication of a bi-weekly newsletter outlining significant developments in the law and demonstrating specific problems and solutions encountered by the medico-legal office. A patient education program could be acconuplished by having representatives of the inedico-legal office attend meetings of community groups, offering seminars to the community which would familiarize it with the existence and functions of the office, as well as providing infornation concerning patients' rights and responsibilities under the law. 
co-legal office is to make the system both more responsive to patients and to simultaneously decrease the number of malpractice suits.

\section{CONCLUSTON}

Catastrophic health msurance or credit-subsidy proposals will not have much impact on the manner in which health care is currently delivered. However, a system of comprehensive health insurance, available to all, will. Under such a plan the current tort system should be retained as the primary method for quality control, and deductibles added to the insurance policies both to increase incentives for care and to decrease premiums. Alternative methods might, however, be devised to provide more umiversal coverage at a more reasonable cost. It imght also be advisable to limit the role of malpractice litigation to questions of imcompetence and negligence, and assign the compensation function to another mechanism.

In addition, even though the tort system aids in making the health care system inore responsive to patient deinands, hospitalized patients are unlikely to be able to exercise the legal rights necessary to fully participate in medical decisions regarding their health care. In such cases patient satisfaction can be enhanced, and the imcidence of medical malpractice reduced, by the introduction of an effective patient grievance mechanism in every major health care institution. It would be most appropriate for such an office to be imdependent of the health care institution, and imclusion of it im a program of national health insurance seems best.

While there are major problems with the present tort liability system, they are not those commonly ascribed to it by the medical profession. The system should be judged strictly on the basis of cost-effectiveness, quality control, medical coverage, and responsiveness to consumer desires. When evaluated under these criteria, the tort system, with the modifications suggested in this Article, retains an important function in any system of national health insurance. We thus conclude that it is more essential than expendable. 
